\title{
KALEVALAMITTA OPPINEIDEN KÄYTÖSSÄ UUDEN AJAN ALUN SUOMESSA
}

\author{
Kati Kallio
}

E nsimmäisiä suomenkielisiä kirjallisia runoja ei ole ollut tapana ylistää. On pahoiteltu sitä, että varhaisten virsien tekijät eivät halunneet käyttää ympärillään laulettua, pakanalliseksi tulkittua suullista runoa (kalevalamittaa), vaan yrittivät mukailla eurooppalaisia jambisia säkeistömalleja, joita eivät onnistuneet sovittamaan suomen kielelle. Yhtälailla on ajateltu, että kalevalamittaa onnittelu- ja omistusrunoihinsa soveltaneet varhaiset oppineet eivät tunteneet tai tajunneet suullisen runon olemusta ja käyttivät siksi mittaa väärin. Näillä ajatuksilla on pitkät juuret (esim. Krohn 1862; 1880; Kurvinen 1941; Porthan 1983 [1766-1778]; Sarajas 1956; Tarkiainen 1922; 1929). Ne kertautuvat eri muodoissa perinteen- ja kirjallisuudentutkimuksessa yhä, vaikka 1900-luvun lopulta lähtien vanhoja lähtökohtia on monin tavoin myös purettu (esim. Häkkinen 2013; Laitinen 2005; 2006; Niinimäki 2007; ks. myös Hannikainen 2006).

Tässä artikkelissa pohdin, miltä 1500- ja 1600-lukujen suomenkieliset runoaineistot näyttävät, kun perinteisiä ennakko-oletuksia käännetään ympäri ja aineistojen kirjoa katsotaan oppialarajoja laajempina kokonaisuuksina. Kun heitetään syrjään ajatus siitä, että varhaisen virsirunouden olisi pitänyt noudattaa 1800-luvun lopun poeettisia ideaaleja tai että oppineiden olisi tullut kirjoittaa mahdollisimman "aitoa" klassista kalevalamittaa, näyttäytyy uuden ajan alun runous laajana ja taidokkaanakin kirjona erilaisia runokielten sovelluksia, joita olisi syytä tutkia aiempaa tarkemmin. Emme tiedä, millaisia hyvän runon kriteerejä kirjoittajilla tai heidän aikalaisyleisöillään oli. Luultavasti nämä vaihtelivat sen mukaan, mihin tarkoitukseen tai minkälaisen lajin edustajaksi mikäkin runo hahmotettiin. Piirteiden käytön yleisyys ja runojen käyttöikä tai käytön laajuus on yksi apu runojen aikalaisarvon pohtimiseen. Jos esimerkiksi miltei kaikki aikakauden suomenkieliset kirjoittajat suhtautuivat sallivasti painollisten tavujen esiintymiseen runon painottomissa asemissa, ei voi ajatella piirteen olleen aikalaisille osoitus huonosta runosta. Ei liioin näytä aiheelliselta olettaa, että ensimmäisiä virsiä olisi syntyaikoinaan pidetty epäonnistuneina, sillä niitä kuljetettiin mukana virsikirjan painoksesta toiseen ja laulettiin satoja vuosia.

Oppineiden käyttämät kirjalliset runomuodot ja heidän kristillisiin traditioihin sitoutuvat uskomusmaailmansa ovat tallentuneet paljon paremmin kuin niiden kansanomaiset vastineet. Oppineet ja kansanomaiset runomuodot ja uskomusmaailmat ovat kuitenkin olleet vuorovaikutuksessa, mistä on myös tallentunut jälkiä 
(Häkkinen 2013; Laitinen 2006). Peter Burke (2009) on arvioinut, että aina 1700-luvulle asti Euroopan kansankulttuurit olivat monin osin myös oppineiden jakamaa suullista kulttuuria. Oletus paikallisen suullisen kulttuurin jakamisesta ei kuitenkaan tarkoita sitä, etteivätkö oppineet olisi voineet samalla identifioitua myös yleiseurooppalaisiin, kirjallisiin tai ainoastaan eliitin jakamiin perinteisiin.

Tämän artikkelin keskiössä on kysymys uuden ajan alun oppineiden suhteesta heitä ympäröineeseen ja ainakin osin heidän jakamaansakin suulliseen runouteen. Olen tarkastellut 1500- ja 1600-lukujen suomenkielisiä runoaineistoja suhteessa siihen, mitä tiedetään toisaalta aikalaisrunoudesta muilla kielillä ja toisaalta myöhempien vuosisatojen kansanomaisista laulukulttuureista. Aineisto on koottu osin aikaisemman tutkimuksen, osin julkaistujen aineskokoelmien perusteella. Se koostuu lähinnä virsistä ja liturgisista lauluista (ks. Kurvinen 1929; Kurvinen 1941), oppineiden "tilapäärunoista" (ks. Melander 1928), asiakirja- ja kirjeaineistoista (ks. Grotenfelt 1912; VKK), pilkkalauluista (ks. Asplund 2006) sekä aikakauden kieliopeista (ks. Lauerma 2012). Työ pohjaa runomitan piirteiden - tavujen painojen ja pituuksien, säe- ja lauserakenteiden, alkusointujen, säkeenkertojen ja riimien - erilaisten käyttötapojen analyysiin ja etenee esimerkkien varassa. Aikakauden koko runoaineiston perinpohjainen analyysi on yhä tekemättä. Asetelmani sivuaa myös erilaisten mittajärjestelmien ja runotyylien rajoja ja niiden kantamia uskomusmaailmoja. Minkälaisia sävyjä voi olettaa kalevalamitan kantaneen mukanaan (ks. Häkkinen 2013; Lehtonen (tulossa)), ja missä mahtoivat uuden ajan oppineiden näkökulmasta kulloinkin kulkea vanhan suomalaisen runomitan rajat? ${ }^{1}$

\section{KaleVALAmitta JA RIIMILLINEN RUNO}

Uuden ajan alun runoaineistot on usein kuvattu tavalla tai toisella vajaina, kömpelöinä tai alkeellisina (esim. Krohn 1880; Sarajas 1956; Tarkiainen 1922; 1929; Viinamäki 2005.) Ehdotan etnopoetiikaksi kutsutun tutkimussuuntauksen perustelemaa näkökulman vaihdosta (Hymes 1981; Tedlock 1983). Oletan, että runot olivat syntyaikakausiensa inmisille valtaosin mainiota tai ainakin kelvollista runoutta ja keskityn pohtimaan, minkälaisin keinoin tekstit on rakennettu. On esitetty, että erilaiset kirjalliset ja suulliset, oppineet ja kansanomaiset runouden muodot muodostavat ennemminkin jatkumoita kuin erillisiä kokonaisuuksia (Foley 2002). Esimerkiksi virsirunous oli oppineiden ensisijaisesti suomenkielisen rahvaan kuunneltavaksi ja käytettäväksi kirjoittamaa suullis-kirjallista runoutta, joka muodostui nähdäkseni suhteessa sekä suullisiin että kirjallisiin runon ja laulun lajeihin.

Suullisille ja suullis-kirjallisille runokielille on usein yleistä yksittäisten tavujen laulamatta jättäminen tai niiden täydentäminen ainoastaan lauletuissa muodoissa, säekohtaisten tavumäärien vaihtelu, riimin suhteellisuus ja laulun rakenteen monitulkintaisuus (Ks. Laitinen 2003; Niemi 1998; Reichl 2000; Kallio 2013). Heikki Laitinen esittää, että varhaiset virret runoiltiin luultavasti enemmänkin tiettyihin sävelmiin sopiviksi kuin abstrakteihin mittakaavoihin, ja juuri tämä teki niistä keuksellisen osuvia ja tarpeellisia. Työhön ovat merkittävästi vaikuttaneet myös keskustelut etenkin Heikki Laitisen, Tuomas Lehtosen, Kaisa Häkkisen, Eeva-Liisa Bastmanin, Senni Timosen, Irma-Riitta Järvisen, Ilkka Leskelän ja Linda Kaljundin kanssa. 
Kati Kallio: Kalevalamitta oppineiden käytössä uuden ajan alun Suomessa

lauluina toimivia. (Laitinen 2003, 183, 211; 2005, 156.) Pirjo-Liisa Niinimäki toteaa, että virsien kulkiessa suullisena perinteenä taju tavujen sijoittamisesta sävelmän rytmiin kulki runotekstien mukana. Sitä vastoin pelkästään tekstinä ja nuottina tarkasteltuna tavujen sijoittuminen laulun rytmiin tai runomitan abstraktiin rakenteeseen on usein monitulkintaista. (Niinimäki 2007, erit. 36; ks. myös Kontio 2001, 88-89.)

1600-luvun myötä oppineet käsitykset hyvästä runomitasta tiukentuivat. Tätä voi tarkastella myös osana kirjallistumisprosessia. Kun runoja alettiin tarkastella kirjallisina teksteinä ennemmin tai yhtä hyvin kuin kuuloaistimuksina, alettiin kiinnittää huomiota enemmän tekstin säännöllisyyteen ja muodon yksiselitteisyyteen (Laitinen 2003, 163-200; Niinimäki 2007). Saksalaisen ja skandinaavisen kulttuurialueen osalta keskeinen oli vuonna 1624 julkaistu saksalaisen Martin Opitzin runomittaoppi, joka asetti tavoitteeksi täydellisen riimin, katkaisemattomat sanat, selkeän eron trokeen ja jambin välillä sekä tavuluvultaan vakioidut, säntilliset runosäkeet (Gasparov 1996, 194-197; Gillespie 1971). Opit näkyivät vahvasti 1600luvun jälkipuoliskon suomenkielisissä virsissä sekä oppineiden onnittelu- ja omistusrunoissa (Kurvinen 1929; Melander 1928).

Anakronistisesta sävystä huolimatta käytän folkloristiikan tutkimusperinteessä vakiintunutta käsitettä kalevalamitta tarkoittamaan vanhakantaista itämerensuomalaista suullista runomittaa. Klassisella kalevalamitalla tarkoitan Kalevalan sekä lähinnä vienankarjalaisten ja inkeriläisten, tutkijoiden parhaimpina pitämien suullisten runojen pohjalta hahmotettua runomitan muotoa. Klassisen muodon ehdot pätevät kuitenkin ainoastaan osaan vanhan itämerensuomalaisen runon laulukulttuureista ja lajeista. Käytännössä vanha suullinen runo on elänyt tätä moninaisempina paikallisyhteisöihin, lajeihin ja laulutilanteisiin liittyvinä variaatioina (Frog \& Stepanova 2011; Kallio 2013; Lauerma 2001; 2004; Sarv 2008). Kalevalamitan tai suullisen laulun variaation rajat 1500-luvun Länsi-Suomessa ovat lähteiden ulottumattomiin jäävä kysymys. 1800-luvulla tallennetussa aineistossa mitan rajat ovat laajat ja huokoiset (ks. SKVR).

Kysymys runomuotojen, esitystapojen ja paikallisten puhekielten suhteista on monisyinen. Esimerkiksi Raja-Karjalassa on ilmeisesti ollut laulutyylejä, joissa kalevalamittaisia säkeitä on voitu muokata tavanomaista pidemmiksi, jopa kaksitoistatavuisiksi (esim. SKS KRA Pelkonen 256), ja ainakin Inkerissä on ollut tiettyjen laulutyylien yhteydessä mahdollista jättää säkeen viimeinen tavu laulamatta (Kallio 2013, 146-149). Puhekielen muutokset, kuten sanamuotojen lyhentyminen, ovat osaltaan vaikuttaneet runosäkeisiin. Petri Lauerma on todennut, että suullisissa runoissa kielen muodot kantavat usein ikään kuin muistoa edeltäneistä muodoista. Sanoja käytetään runoissa yhä perinteisin tavoin, vaikka pintatasolla kielen muutokset näyttävät tekevän runosäkeistä virheellisiä. Lyhentyneitä sanamuotoja on laulettaessa voitu täydentää lisätavuilla tai vain venyttää niitä kattamaan useampia runoasemia. (Lauerma 2001; 2004, 24-65; myös Kallio (tulossa).) Sanoja on myös voitu jakaa tavuiksi useammilla tavoilla, runomitan tai laulun rytmin edellyttämillä tavoilla (Leino 1986, 71-75). Toisaalta kansanperinteen tallennustilanteissa yleinen runojen saneleminen on voinut osaltaan joko pidentää tai lyhentää säkeitä (Saarinen 1988, 198-199; ks. myös Lauerma 2004, 24). Laulun rytmi on osaltaan 
Kati Kallio: Kalevalamitta oppineiden käytössä uuden ajan alun Suomessa

vakauttanut suullisen runon rakenteita. Etenkin lajit, joita ei juuri esitetty laulaen, kuten sananlaskut ja lyhyemmät loitsut, esiintyivät usein klassisen kalevalamitan ja proosan välillä varioivissa muodoissa.

Idealisoitujen runomittojen käyttäminen auttaa silti hahmottamaan varioivien runokielten ytimet. Esitän yleiskuvaukset klassisesta kalevalamitasta ja tyypillisistä riimillisen runon mitoista, jotta lukijan olisi helpompi hahmottaa niitä akseleita, joilla tarkastelu liikkuu. Käytännössä eri mittajärjestelmiin abstrahoidut piirteet ovat kuitenkin eri aikoina ja eri lajien puitteissa liittyneet toisiinsa moninaisin tavoin.

Ajatellaan, että kalevalamitta on yli tuhat vuotta vanha itämerensuomalainen runokieli, joka on kehittynyt tiiviissä yhteydessä kielen rakenteiden kanssa. Se sopii esimerkiksi huomattavan hyvin yhteen monien vanhakantaisten kielen muotojen kanssa. (Leino 1986; 1994; Korhonen 1994; Kuusi 1994.) Runokielen laaja maantieteellinen levinneisyys Länsi-Suomesta Venäjän Karjalaan ja Viroon sekä suuri lajikirjo epiikasta ja lyriikasta häälauluihin, sananlaskuihin ja kehtolauluihin puhuvat osaltaan pitkän historian puolesta (Kuusi 1994; lajikirjosta ks. Siikala 2012; Tarkka 2005; Timonen 2004). Mitasta on vaihtelevia muotoja. Esimerkiksi Etelä- ja Länsi-Virossa ja Länsi-Suomessa säännöt painollisten tavujen sijoittumisesta eivät ole yhtä tarkkoja kuin klassisessa kalevalamitassa, minkä on ajateltu voivan liittyä kielen muutoksiin, mutta toisaalta voivan olla myös vanha, jopa klassista kalevalamittaa edeltänyt piirre (Kuusi 1994, 44; Laitinen 2006; Leino 1994, 71; Sarv 2008).

Klassinen kalevalamitta on riimitön ja säkeistötön runomuoto. Se koostuu 8-10-tavuisista säkeistä, jotka jaottuvat neljään runojalkaan eli kahdeksaan runoasemaan. Ensimmäisessä runojalassa voi olla 2-4 tavua, muissa on yleensä kaksi. Säkeen viimeinen tavu voi jäädä esittämättä (Kallio 2013, 146-149; Lauerma 2004, 24). Klassisessa kalevalamitassa pitkät pääpainolliset tavut sijoittuvat runojalan nousuun eli mitan painollisille kohdille, lyhyet pääpainolliset tavut laskuun eli mitan painottomille kohdille. Ensimmäistä runojalkaa tämä sääntö ei kuitenkaan koske, ja toisessakin jalassa siitä poiketaan useammin kuin säkeen loppupuoliskossa. Suomen kielessä pääpainolliset tavut ovat sanan alkutavuja, ja tavut ovat lyhyitä, jos ne loppuvat lyhyeen vokaaliin (e-, le-). Säetyyppejä klassisessa kalevalamitassa on kaksi: normaalitrokee, jossa sanapainot ja runomitan painolliset asemat osuvat yksiin (vaka| vanha| Väinä-|möinen) ja murrelmasäe, jossa lyhyt pääpainollinen tavu (i-) osuu säkeen painottomille osille (tietä-|jä i-|jän i-|kuinen). Säkeen sisäinen alkusointuisuus on runsasta, mutta se ei aina sido kaikkia säkeen sanoja yhteen tai esiinny jokaisessa säkeessä. Monimuotoista parallelismia eli säkeenkertoa esiintyy. Runon lauserakenne mukailee säerakennetta. (Leino 1986, Kuusi 1949, Sadeniemi 1951, Saarinen (tulossa).) Jatkossa tehtävien tulkintojen kannalta olennaista on korostaa, että moitteetonta klassista kalevalamittaakin noudattavat säkeetkin voivat käytännössä olla seitsemästä kymmeneen tavua pitkiä ja tavunpainorikkeet ovat sitä sallitumpia, mitä lähempänä ne ovat säkeen alkua.

Riimilliset runot muodostavat klassista kalevalamittaa laajemman muotojen kirjon. Niitä on kutsuttu monilla, eri piirteitä kuvaavilla nimillä: riimillinen, säkeistöllinen tai uusimittainen runo tai laulu. Niille on tyypillistä riimin käyttö, jakautuminen 
määrämittaisiksi säkeistöiksi ja runomitan perustuminen sanapainoille. Toisin kuin klassisessa kalevalamitassa, painollisten tavujen pituuksilla ei yleensä ole merkitystä, vaan sekä lyhyt että pitkä pääpainollinen tavu sijoittuvat runomitan painollisiin asemiin eli nousuihin. Vokaalien väliset tavurajat tulkitaan välillä vaihtelevin tavoin, ja tietyt kaksitavuiset sanat (ehkä, koska) on mahdollista tulkita joko painottomina tai painollisina. Alkusointua ja säkeenkertoa voi esiintyä, mutta ne eivät ole samalla tavoin keskeisiä kuin kalevalamitassa. Säkeistöjen ja säkeiden pituus ja runomitan luonne vaihtelee runoittain. Riimilliselle kansanlaululle ja varhaisimmille kirjoitetuille runoille on tyypillistä, että runojalan sisältämien tavujen määrä voi vaihdella, jambisen säkeen aloittava kohotavu voi esiintyä vaihdellen ja säkeiden toteutuneet painorakenteet voivat olla epäsäännöllisiä. Yleisilmeeltään jambiseen runoon oli esimerkiksi mahdollista sijoittaa trokeisia säkeitä. Puhunkin jambisista ja trokeisista mitoista ennemmin kuin puhtaasta trokeesta ja jambista. Jambisten rakenteiden siirtäminen suomen kielelle ei kielen indoeurooppalaisista kielistä poikkeavan rakenteen vuoksi ollut helppoa. On vaikeaa aloittaa säe painottomalla tavulla, kun yksitavuisia sanoja on kielessä niukalti ja useampitavuisten sanojen ensimmäinen tavu on aina painollinen. (Asplund 1997; Laitinen 2003; Laurila 1956; Leino 1986; Niinimäki 2007; varhaisten virsien mittatulkinnoista ks. myös esim. Hallio 1936; Krohn 1880, 48-50; Lempiäinen \& Haapalainen 1971; Väinölä 1995.)

Varhaisimmat lähteet sekä kansanomaisesta että oppineesta, kalevalamittaisesta että riimillisestä suomenkielisestä runosta sijoittuvat reformaation jälkeiselle ajalle (ks. Asplund 2006; Häkkinen 2012; 2013). Ensimmäiset tunnetut säkeistömuotoa tai riimiä käyttävät suomenkieliset runot ovat esipuherunoja, hymnejä ja liturgisia lauluja Mikael Agricolan ja hänen aikalaistensa teoksissa (Häkkinen 2012), mutta muutamien pikkusäkeistöjen on ajateltu voivan periytyä keskiajalta (Gummerus 1931). Käytettävissä olevien lähteiden pohjalta on yleensä oletettu sekä suullisen että kirjallisen riimillisen, säkeistöllisen runouden alkaneen varsinaisesti kehittyä Länsi-Suomessa reformaation aikoihin ja nousseen valta-asemaan 1700-luvulta alkaen (Leino 1994, 56-57; ks. myös Asplund 2006; Enäjärvi-Haavio 1953, 220222). Riimillisen laulun rinnalla kalevalamitta muunnelmineen säilyi 1900-luvulle asti.

Kalevalamittaisen ja riimillisen runon tyypillisimmät ja helpoiten kuultavissa olevat erot voidaan pelkistää kolmelle akselille: alkusointu kuuluu yleensä kalevalamittaan, riimi uusimittaisiin runoihin. Säkeistömuotoa esiintyy riimillisissä runoissa, kalevalamitta rakentuu lauserakenteiden ja paralleelijaksojen varaan. Murrelmasäkeitä eli lyhyttä painollista tavua painottomassa asemassa esiintyy säännönmukaisena vain kalevalamitassa, tavumäärän vaihtelua runoasemassa (1-2) ainoastaan riimillisissä mitoissa (kalevalamitan ensimmäistä runojalkaa lukuun ottamatta). Puhtaat trokeesäkeet voivat kalevalamitassa ja riimillisissä mitoissa rakentua paikoin täysin samanlaisiksi, ja tietynlaiset kalevalamitan murrelmasäkeen kaltaiset säkeet voivat mainiosti toimia neli-iskuisina jambisäkeinä.

Käytän pystyviivaa | havainnollistamaan tulkitsemiani runojalkojen rajoja. Useissa tapauksissa säkeiden tavurakenteita ja joskus jopa runon metristä pohjarakennetta voisi tulkita useammalla tavalla. Kaikista monitulkintaisimmat tai oman tulkintani vastaiset säkeet on merkitty asteen merkillä॰, klassisen kalevalamitan sääntöjen 
vastaiset tavut paikoin kursiivilla. Runosäkeen yleistä metristä rakennetta kuvaan plus- ja miinusmerkeillä +---+---. Plusmerkki vastaa painollista asemaa ja miinus painotonta, murrelmasäkeitä merkintätapa ei ota huomioon. Sulut (+) ilmaisevat metristä asemaa, joka voi osassa säkeitä jäädä täyttämättä. Mahdollinen tavumäärä metrisessä asemassa vaihtelee runon lajin ja tyylin mukaan, mutta on tyypillisesti yhdestä kahteen tavua (eli kahdesta neljään tavua runojalassa). Aina runon kaikki säkeet eivät vastaa abstraktia metristä rakennetta: kyseessä siten on ennemminkin luonnehdinta runon tai säkeen yleishahmosta kuin jokaista säettä koskeva ehdoton malli. Tulkinnassa on otettu huomioon myös sävelmän ja mahdollisen muunkielisen alkutekstin rakenne. Tekstien kirjoitusasu vastaa lähteitä, mutta pilkkua tarkoittavat kauttaviivat / olen selvyyden vuoksi vaihtanut pilkuiksi. Rivijaot ovat pääosin itse tekstin rakenteen perusteella tulkitsemiani.

\section{ReFORMAATIOAJAN KESKIAIKAISET PERINTEET}

Ensimmäiset reformaation jälkeiset vuosikymmenet suomenkielinen luterilainen laulu perustui ilmeisesti lähinnä vapaamittaisille teksteille ja muutamille kkeskiaikaisten hymnien käännöksille. Mikael Agricola ei julkaissut virsikirjaa, vaikka hänen tuotantonsa muuten kattoi luterilaisen kirkon keskeisimmät teokset ja vaikka ensimmäiset virret ruotsiksi julkaistiin jo vuonna 1526. Vaikuttaa siltä, että Agricolalla ei ollut mahdollisuuksia tai tarvetta yrittää luoda sellaista luterilaista virsilaulukulttuuria, joka saksalaisella alueella hänen aikanaan jo vallitsi. (Heininen 2007; Häkkinen \& Vaittinen 2007; Knuutila 1997.) Kääntäessään Rukouskirjan, Uuden testamentin, Psalttarin psalmit ja muita Vanhan Testamentin tekstejä Agricola kuitenkin käänsi myös aineiston suomenkielistä, jumalanpalveluksissa välttämätöntä liturgista, lähinnä suorasanaista laulua varten (Häkkinen 2007, 19; Tuppurainen 2012, 32-33).

Reformaation suhde latinan kieleen ei ollut ehdoton. Vielä 1600-luvun alussa voitiin jumalanpalveluksissa suomenkielisten virsien ohella yhä laulaa myös latinaksi ja ruotsiksi (Pajamo \& Tuppurainen 2004, 46; Schalin 1946-1947), ja vielä vuonna 1605 sovitettiin vanhoja suorasanaisia latinankielisiä liturgisia lauluja suomeksi (Hannikainen 2006). Luther tai Agricola eivät suinkaan halunneet lopettaa latinan käyttöä, vaan tuoda kansan kielen sen rinnalle niitä varten, jotka eivät latinaa ymmärtäneet (Agricola I, 92: Herl 2004; Leaver 2007, 18, 144, 180-191).

Kirjojen esipuherunot muodostavat valtaosan Agricolan runotuotannosta. Abc-kirjan, Rukouskirjan ja Psalttarin esipuheissa Agricola käytti saksan- ja ruotsinkielisissä esipuheissa yleistä knitteliä eli neli-iskuista, riimillistä parisäettä, jonka tavumäärä vaihteli. Samankaltaisia riimillisiä muotoja oli laajasti käytössä skandinaavisessa ja germaanisessa aikalaisrunoudessa, ilmeisesti sekä suullisina että kirjallisina. (Häkkinen 2012; 2013.) Agricolan knitteli on väljä neli-iskuinen mitta: (-)+--+-+-+--, jossa yhteen runoasemaan voidaan sijoittaa yhdestä kahteen tavua. Alkusointua tai kalevalamitan murrelmasäkeen kaltaisia tavurakenteita ei esipuherunoissa juuri näy. Knittelille tyypilliset trokeesäkeet voivat satunnaisesti vastata täysin kalevalamitan trokeesäkeitä, kuten Abc-kirian alkusäkeiden neljäs säe. Vaikka muutkin säkeet näyttävät asettuvan neljään runojalkaan, on niissä klassisen kalevalamitan kannalta pitkiä ja lyhyitä painollisia tavuja väärissä paikoissa: 
Kati Kallio: Kalevalamitta oppineiden käytössä uuden ajan alun Suomessa

[http://www.elore.fi/arkisto/1_15/kallio.pdf]

Oppe| nyt wan|ha, ia| noori, ${ }^{\circ}$

joilla| ombi| Sydhen| toori.

Juma|lan kes $\mid \mathrm{kyt}$, ia| mielen ${ }^{\circ}$

iotca| taidhat| Somen| kielen. [...]

(Agricola I, 1.)

Etenkin Psalttarin esipuheessa monet säkeet ovat huomattavasti pidempiä: "Joska se Jocapeiue prucattaisin, ette Bibliast iotaki luetaisin" (Agricola III, 211). Kaisa Häkkisen mukaan Agricolan runoissa on ainoastaan 20 klassista kalevalamittaa vastaavaa säettä, jotka selittyvät runomuotojen osittaisen samankaltaisuuden kautta (Häkkinen 2013, 60).

Lähes kaikki Agricolan julkaisemat laulettaviksi tarkoitetut tekstit liittyvät keskiajan kirkolliseen perinteeseen. Mitalliset tekstit olivat perinteisesti keskeisiä etenkin rukoushetkien ja kirkkovuoden suurimpien juhlien yhteydessä. Niiden piirissä oli erilaisia trokeisia ja jambisia, riimillisiä ja riimittömiä, säkeistöllisiä ja parisäkeille rakentuvia muotoja (Page 2010; Kurvinen 1929). Agricolan julkaisemista lauluista mitaltaan säännöllisin on Kultainen sekvenssi (Veni sancte Spiritus, et emitte coelitus), yksi keskiaikaisen kirkon keskeisimmistä hymneistä (Kurvinen 1929, 230231; Codex Westh 2012b, 17, 36-38). Runon trokeinen muoto (+-+-+-+) on selkeä ja säkeiden tavumäärä säännöllinen, riimiä esiintyy eri säkeistöissä vaihdellen:

TUle| Pyhe| hengi| ten alas|laske| Taijua|hast sinun| paijstes| walke|us Tule| kieuhett|en I|se tule| lahian| andailja tule| sijelun| kirca|us. [...] (Agricola I, 409.)

Alkusointua ei Agricolan julkaisemissa trokeisissa runoissa juuri esiinny, jambisissa se on yleisempää. Perinteisen keskiaikaisen hymnin Christe, qui lux es et dies käännöksen muotti on jambinen tetrametri (-+-+-+-(+)), mutta tavujen määrä runoasemissa vaihtelee jonkin verran eri säkeistöissä (Kurvinen 1929, 235-237; Codex Westh 2012b, 92-94):

CHristus| se paijs|te ia peij|ue on quin öön| pimey|dhet hai|jotat sine wal|keud|hen wal|keus sarna|tat py|hen paijs|teen. [...] (Agricola I, 681).

Säkeiden muoto on kaukana kalevalamitasta, mutta alkusointua esiintyy melko runsaasti. Näyttää siltä, että Agricolan julkaisemissa trokeisissa hymneissä vältettiin tarkemmin kalevalamitan piirteitä - lähinnä satunnaista alkusointua, mutta myös lyhyttä painollista tavua painottomassa asemassa - kuin jambisissa. Tulkitsisin tämän kertovan tarpeesta tehdä ero eri laulun lajien tai rekistereiden välille. Jambinen rakenne on kauempana kalevalamitasta, joten satunnainen alkusointu ei vielä saa laulua kuulostamaan kalevamittaiselta. Kirkolliset laulut hahmottuivat näin erillisenä lajinaan. Agricolan ajan mitalliset laulut ovat tosin pieni ja monitulkintainen aineisto. 
Varsinaista kalevalamittaa ei Agricolan runoissa ole. Kokonaan hän ei silti mittaa karttanut, huomautti jo Annamari Sarajas (Sarajas 1956, 5-9; ks. myös Häkkinen 2013, 63-65). Agricola julkaisi Rukouskirjan kalenteriosassa kansanomaisen hokeman sekä sananlaskun "Satehixi peijuen sappi / Poudixi Cuum kehä" (Agricola I, $60,72)$. Sananlaskusta on Länsi-Suomessa käytetty myös esimerkiksi variaatiota "Poutia kuu kehii, satehia päivän sappi" (Vartia 1907, 225). Näyttää siltä, että sana kuu on voitu runoissa käsittää myös kaksitavuisena, kahta runoasemaa vastaavana (ku-u; kuuhut; ks. esim. SKVR X 1 99; SKVR IX 1 41; SKSÄ L 427, säe 73). Sanojen kehä ja kehii taas voi olettaa kantaneen muistumia kielen vanhemmista tai runokieleen liittyvistä muodoista: "poudik|si ku-|un ke|hänen" (tai "pouta|siksi| kuun ke|hänen"), "pouti|a kuu|hut ke|hivi". Tällöin sananlasku variaatioineen hahmottuisi taustarakenteeltaan selkeän kalevalamittaisena. Myös Agricolan julkaiseman hokeman monet säkeet näyttäisivät tunnistettavammilta, jos säkeiden ajattelisi kantavan muistumaa sanojen pidemmistä muodoista (Kymmenen| kuuta| naura|vainen; seitsemän kuu|ta mö|kettä|väinen; vrt. SKVR X 2030 ; XII 2199 ).

Näyttää siltä, että Agricola oli sangen tietoinen runouden lajeista ja eroista. Kalevalamitta ei hänelle ollut esipuherunojen tai perinteisten hymnien kieli, mutta ei liioin ehdottoman vältettävä muoto. Mitta itsessään ei kantanut sellaisia epäkristillisiä assosiaatioita, etteikö sille rakentuvia sananlaskuja olisi voinut käyttää ja julkaista. Klassista kalevalamittaa Agricolan kansanrunoesimerkitkään eivät kuitenkaan pintatasollaan olleet.

\section{LUTERILAINEN, RIIMILLINEN VIRSILAULU}

Vasta vuonna 1583 Turun katedraalikoulun rehtori Jacobus Finno (Jaakko Suomalainen) julkaisi ensimmäisen suomenkielisen virsikirjan ja loi samalla varsinaisen luterilaisen, seurakunnan laulettavaksi tarkoitetun virsilaulun. Finnolle virret tarkoittivat jambista, riimillistä säkeistölaulua. (Knuutila 1997; Kurvinen 1929, 231, 256-312; Lempiäinen 2012; Lehtonen 2013.) Osa hänen virsistään saattoi olla muiden tekemiä (Kurvinen 1941, 18).

Yleisin, joskaan ei ainoa, Finnon säetyyppi on neli-iskuinen jambisäe. Säkeet yhdistyvät erilaisiksi kahdesta kahteentoista säettä käsittäviksi säkeistörakenteiksi. Vaikka jambisten säkeiden lomiin punoutuu trokeesäkeitä, ei yksikään Finnon virren peruskaava ole trokeinen. (Kurvinen 1929, 76-77; Finno 1988). Tämän voi tulkita eron tekemisenä suullisen runon trokeeseen ja keskiaikaisten hymnien trokeiseen mittaan, mutta yhtä lailla tiiviinä yhteytenä uuteen luterilaiseen, leimallisesti jambiseen virsilauluun.

Kalevalamitalle ominaista alkusointua Finno välttelee ilmeisen tietoisesti. Tuomas Lehtosen mukaan allitteraatiota esiintyy ainoastaan noin $14 \%$ Finnon säkeistä, kun taas myöhempien virsikirjojen uusissa virsissä sitä on Hemminki Maskulaisella noin 50 \% ja vuoden 1701 virsikirjassakin noin $40 \%$ säkeistä (Lehtonen, tulossa). Näyttääkin siltä, että Finno yleensä pyrki jambisten rakenteiden suosimisen ja allitteraation välttämisen kautta etäälle kalevalamitasta. 
Kati Kallio: Kalevalamitta oppineiden käytössä uuden ajan alun Suomessa

[http://www.elore.fi/arkisto/1_15/kallio.pdf]

Kalevalamitan piirteiden välttämiseen on joitain poikkeuksia. Kaikkein lähimpänä kalevalamitan rakenteita liikkuu jambinen virsi Christuxen pijnast ia cuolemast:

Christu|xen pij|na muis|tacam

Ja mei|täm syn|nist suis|tacam

Quin hä|nen cuo|leman| waati

Ja mei|dhät cadho|tuxen| saatti. ${ }^{\circ}[\ldots]$

(Finno 1988, 275.)

Jambinen runomitta (-+--+-+-+) on tässä laulun alkusäkeistössä sangen säntillinen: ainoastaan kahdessa säkeessä esiintyy painollinen tavu painottomassa asemassa. Viimeisen säkeen "ylimääräiselle" tavulle on oma paikkansa laulun sävelmässä (ks. Haapalainen \& Tuppurainen 2004, sävelmä 115). Myöhempänä samassa virressä Finnolla on myös puhtaita trokeesäkeitä ("Pappein| ethen| iodha|tettin") ja jopa yksitoistatavuisia säkeitä kahdeksantavuisen säkeen muottiin sovitettuna. Muutamat jambisäkeet voisi halutessaan lukea myös kalevalamittaisina murrelmasäkeinä ("Ja oikeu|dhen e|ten we|dhettin"), vaikka valtaosassa murrelmasäettä muistuttavista säkeistä olisi vähintään yksi sanapaino väärässä paikassa ("Cunnia |sekä |mös y|listös").

Julius Krohn ajatteli väitöskirjassaan, että yllä olevan virren mitta on lähellä kalevalamittaa, vaikka teksti ei ensisilmäyksellä siltä näytä (Krohn 1862, 38). Ilmeisesti tämä perustui satunnaisten murrelma- ja trokeesäkeiden ohella myös siihen, että useat virren säkeistä olisivat viimeinen sana täydentämällä tulkittavissa kalevalamittaisiksi trokeesäkeiksi: "Kristuksen| piinal muista|kaam[me], Ja meitä| synnist| suista|kaam[me]." Suuri osa säkeistä ei kuitenkaan ole väännettävissä kalevalamittaiseksi edes tässä virressä. Finno ei kirjoittanut kalevalamittaa ja tuntuu yleensä välttelevän suullisen runon piirteitä, mutta kalevalamitan kaltaisia säerakenteita hänelläkin hetkittäin esiintyy yllättävinä tihentyminä. Tämä saattaa viitata muihin suomentajiin Finnon joidenkin virsien taustalla, alalajikohtaisiin poikkeuksiin tai vain kielen tiedostamattomaan rytmittymiseen suullisen runon kaltaisesti.

Finno kertoo olleensa vaikuttunut saksankielisestä virsilaulusta, sen voimasta ja leviämisestä kansan keskuuteen (Finno 1988, 14-15). Samankaltaiset säkeistömuodot muodikkaine sävelmineen olivat käytössä pitkin Eurooppaa. Kalevalamitta edusti toisenlaista, säkeittäin etenevää muotoa, jossa myös säkeiden syntaksi rakentui hyvin toisenlaisella tavalla (ks. Saarinen, tulossa). Kalevalamittaan vahvasti perustuvasta virsilaulusta olisi tullut hyvin toisenlaista kuin mitä olivat muiden luterilaisten seutujen laulukulttuurit. Edes teoriassa kahdeksantavuinen trokeesäe ei olisi istunut kaikkiin virsisävelmiin. (Ks. myös Häkkinen 2013; Laitinen 2005.) Todennäköisesti erilaiset laulurekisterien piirteet - säe- ja säkeistörakenteet, riimi tai allitteraatio, sävelmät, käyttökontekstit, tyypilliset sisällöt, esitystavat - assosioituivat käyttäjien mielissä kokonaisuuksiksi, joiden osat saivat merkityksiä toisiltaan (vrt. Agha 2004). Luterilaisesta virrestä rakennettiin oma, sekä paikallisesta suullisesta runosta että osin myös keskiaikaisista muodoiltaan varioivista hymneistä erottuva ja "muidhen Christilisten maacundain" lauluun liittyvä lajinsa (Finno 1988, 175). Yllättävämpää kuin Agricolan ja Finnon laulujen kalevalamittaa karttavat rakenteet onkin nähdäkseni se, että heidän jälkeensä kalevalamitan piirteet nousivat nopeasti keskeiseksi osaksi myös säkeistöllisiä, riimillisiä virsiä. 


\section{Alkusoinnulliset VirRet}

Jacobus Finnon virsikirjan aikoihin suullisen runon piirteitä alettiin toisaalla ottaa kansankielisen virren osaksi. Voi olla, että kyseessä oli papiston kesken käyty neuvottelu tai kiista siitä, missä suhteessa suomenkielisen seurakuntalaulun tulisi olla yhtäältä suullisen runon muotoihin, toisaalta keskiajan kirkollisiin perinteisiin, joissa sekä trokeella että säkeistöttömällä laululla oli sijansa jambin ja säkeistömuodon rinnalla.

Vuoden 1583 tienoilla Tukholman suomenkielisen seurakunnan piirissä toiminut tuntematon runoilija kirjoitti kaksi perinteistä helatorstai- ja pääsiäishymnejä mukailevaa laulua jambisella ja riimillisellä, mutta samanaikaisesti kalevalamitan rakenteille nojaavalla mitalla (-+-+----+-). Riimin käyttö on epäsäännöllistä, eikä teksti muodosta selkeitä säkeistöjä. Alkusointua käytetään runsaasti. Valtaosa hymnien säkeistä olisi helppoa muuttaa kalevalamittaisiksi usein vain lisäämällä loppuun poisjätetty tavu ('"Hyvä| herra| herra| Krist[us], Se suuri| kunni|an ku|ningas, isäns| tahdon| täytti| tääl[lä][...]"). Joukkoon tulisi näin tulkiten murrelmasäkeitäkin. (Rapola 1934; ks. myös Häkkinen 2013, 69-72.) Alkuperäisteksti on kalevalamittaisesta taustarakenteestaan huolimatta rakennettu selkeän jambiseksi:

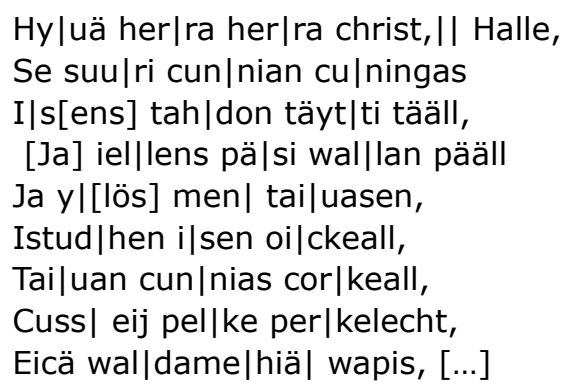

"Halle" viittaa jokaisen säkeen jälkeen laulettuun halleluja-kertaumaan, ja käsikirjoituksen vaurioituneet kohdat Martti Rapola on täydentänyt myöhempien painettujen versioiden pohjalta (Rapola 1934). Laulettuna jambinen muoto toimii kauniisti - ensimmäinen tavu on vain lyhyemmissä säkeissä venytettävä kahden runoaseman pituiseksi (sävelmästä ks. Haapalainen \& Tuppurainen 2004, 123).

Suomenkielisen virsikirjan seuraavan, vuoden 1605 edition laatija Hemminki Maskulainen tunsi tuntemattoman runoilijan hymnin. Vaikka hän kirjoitti laulun selkeämmin jambiseen ja säkeistölliseen mittaan, hän säilytti silti monia edeltäjänsä säkeitä ja muotoiluita. Tuntemattoman tekstit otettiin lähes sellaisinaan Olaus Elimaeuksen virsikirjaan vuonna 1621. (Hallio 1936, 124-125; Rapola 1934.)

Näyttää todennäköiseltä, että tuntemattoman runoilijan antama malli vaikutti sekä Hemminki Maskulaiseen että hänen appeensa Petrus Melartopaeukseen - ellei kyseessä sitten ollut vanhempi, suullisena elänyt kirkollisen kansankielisen laulun perinne. Melartopaeus osin muokkasi aikaisemmista käännöksistä ja osin käänsi virsikirjan uuteen painokseen viisi laulua, joista neljä perustui vanhoihin keskiaikaisiin kirkollisiin lauluihin ja yksi Lutherin psalmivirteen (Kurvinen 1929, 317-318, 350, 357-358). Hän käytti estoitta alkusointua ja trokeisia muotoja, joskaan ei 
Kati Kallio: Kalevalamitta oppineiden käytössä uuden ajan alun Suomessa

varsinaista kalevalamittaa. Tekstien kalevalamitankaltaisuus on seitsentavuisissa trokeesäkeissä (+-+-+-+) ilmeistä:

LAulu|ja nyt| laske|cam,

Juma|lastal jutel|cam [...]

(VKK: Hemm1605-135:1-L8a.)

Suurin osa Melartopaeuksen säkeistä ei silti noudata kalevalamitan tavunpituussääntöjä, eikä murrelmasäkeen kaltaisia rakenteita juuri näy. Yllä olevan virren kolmisäkeiset säkeistöt jatkuvat kahdeksansäkeisellä kertaumalla. Kertauman säkeet on taitavasti rakennettu laulun sävelmän ja latinankielisen tekstin hieman varioivan mitan (+-+-+--+-+-+) mukaan.

Jesus caunis helmas macais Maarian,

Gabrielin ennustos on täytetty,

Eija, Eija, Neidzy nuori sikjän sai,

Ilman miehet Pojan toi, qvin caicki loi [...]

(VKK: Hemm1605-135:1-L8a.)

Eniten kalevalamittaisen murrelmasäkeen kaltaisia rakenteita ("Linnal /ujal on Ju|mala") on Melartopaeuksen versiossa Lutherin Ein feste Burg ist unser Gott -virrestä (ks. Hallio 1936, 246). Tässä virressä osa säkeistä on 5-6-tavuisia ja musiikillisestikin muita lyhyempiä, mikä erottaa laulun kokonaisuuden selkeästi kalevalamitasta. Kalevalamitankaltaisuudet painottuvat laulun jambisiin, kahdeksantavuisiin säkeisiin. Alkusointua on Melartopaeuksen käännöksessä yltäkylläisesti. (VKK: Hemm1605-24:1-C3a.) Näyttääkin siltä, että Melartopaeus käytti kalevalamitan kaltaisia piirteitä eniten silloin, kun jokin tekijä laulun rakenteessa - jambinen muoto, kalevalamittaista säettä lyhyemmät säkeet tai sitä pidemmät kertaumat - teki eron suulliseen runoon selväksi. Oman lisänsä antoivat virsien sävelmät, jotka eivät liioin muistuttaneet tyypillisiä runosävelmiä (ks. Haapalainen \& Tuppurainen 2004; vrt. Lippus 1995).

Hemminki Maskulaisen virsissä kalevalamittaisten piirteiden käyttö vaihteli vielä enemmän. Hän näyttää olleen luova runoilija, joka käytti laulusta riippuen vaihdellen erilaisia rakennepiirteitä, kuten riimiä, alkusointua ja erilaisia tavurakenteita. Alkusoinnun ja kalevalamittaisten tavurakenteiden käyttö on hänellä paikoin runsasta, vaikka puhtaasti kalevalamittaisia virsiä hänkään ei kirjoittanut. Valtaosa virsikirjan lauluista on jambisia. (Krohn 1862, 1880; Kurvinen 1929; Kurvinen 1941; Laitinen 2005; Lempiäinen 2000.) Kalevalamitankaltaisten piirteiden käyttö näyttää olevan yleisempää hänen Piae Cantiones -suomennoksessaan kuin virsikirjassa (VKK: Hemm1605; Hemm1616). Julius Krohn toteaa alkusointua myös esiintyvän eniten niissä Hemmingin virsissä, joille ei ole muunkielisiä vastineita (Krohn 1862, 37). Olisiko keskiaikaisiin lauluihin, omiin runoihin ja tämän lisäksi kokonaishahmoltaan selkeästi kansanrunosta eroaviin lauluihin liitetty muita virren lajeja herkemmin kalevalamitan kaltaisia piirteitä?

Kalevalamitan piirteitä säkeistölliseen ja riimilliseen lauluun soveltavien runojen jälkeen kaikki mahdollisuudet erilaisiin sovelluksiin olivat auki. 1600-luvun kuluessa sepitetyissä uusissa, vuoden 1701 virsikirjaan lisätyissä virsissä alkusointuisuutta 
esiintyy lähes yhtä paljon kuin Hemminki Maskulaisella (Lehtonen, tulossa). Johan Cajanuksen taidokas, alkujaan vuonna 1683 arkkiveisuna julkaistu runo ETkös ole Ihmis parca, aiwan arca on tunnetuin vuoden 1701 virsikirjaan otettu kalevalamitan rakenteita soveltava virsi (Hallio 1936,632). Sellaisenaan kalevalamitta ei kuitenkaan viralliseen virsikirjaan sopinut. Cajanuksen runossa selkein erottava tekijä oli suullista mittaa monimutkaisemmaksi puolikkain säkein (aiwan arca) luotu säkeistörakenne.

\section{LUTERILAINEN KALEVALAMITTAINEN KANSANVALISTUS}

Ensimmäinen klassista tyylipuhdasta kalevalamittaa käyttävä luterilainen runo ilmestyi vuonna 1690, kun Kajaanista kotoisin ollut, Inkerissäkin pappina toiminut Matthias Salamnius julkaisi 2265-säkeisen arkkipainatteen Ilo-laulu Jesuxesta. Runo kuvaa Jeesuksen syntymän, elämänkulun ja kuoleman. Kyseessä on siis kristillisen uskon ytimen esittävä, kärsimyshistoriaan keskittyvä kalevalamittainen pienoiseepos. (Sarajas 1956, 86-88.) On mahdollista, että Salamnius sai idean runoonsa ja kenties joitain runosäkeitäkin kainuulaisista ja inkeriläisistä kansanomaisen Luojan virren toisinnoista. Toisaalta laulu saattoi myös vaikuttaa myöhemmin tallennettuihin kansanrunoihin. (Senni Timonen, suullinen tiedonanto.) Salamnius kirjoitti kalevalamitalla myös muistorunon piispa Gezelius vanhemmasta. (Sarajas 1956, 86-88.)

Tiukimman puhdasoppisuuden ajan pappismies siis saattoi laatia perinteisiin kristillisiin kansanrunoihin viittaavan periluterilaisen kansalle suunnatun pienoiseepoksen klassisella, riimittömällä kalevalamitalla ja käyttää samaa runomuotoa myös yhdelle kansanuskon suhteen tiukimmista piispoista tekemässään muistorunossa. Ilo-Laulu saavutti suuren suosion sekä oppineiston että kansan parissa. Seuraavina vuosisatoina arkkina ilmestyneestä laulusta otettiin 16 painosta (Sarajas 1956, 87). Runonkerääjät törmäsivät siihen kansanrunoja tallentaessaan: A. A. Boreniuksen muutaman muistiinpanon mukaan runoa laulettiin tyypillisellä Suomen ja Karjalan alueen viisi-iskuisella niin sanotulla kalevalasävelmällä (Laitinen 2006, 54). Henrik Gabriel Porthan käytti Ilo-Laulua 1700-luvun lopulla runousoppinsa keskeisenä esimerkkinä suomalaisesta kalevalamittaisesta runosta (Porthan 1983 [1766-1778]).

Ilo-Laulun aloittamaa kalevalamitan käyttöä kristillisen kansanvalistuksen välineenä myös jatkettiin. Vuonna 1786 Rantsilan kappalainen Christfried Ganander julkaisi parituhatsäkeisen Runo=kirjan, joka sisälsi kalevalamittaisen Korkean veisun, kaksi psalmia, osan Jobin kirjaa ja kolme hautauslaulua (Laitinen 2006, 53). Toiset käyttivät kalevalamitan oppineita, länsisuomalaisia muunnelmia: Turun tuomiokirkon kappalainen Jonas Mennander julkaisi vuonna 1699 kristillisen huoneentaulun Huonen-Speili kalevalamittaa muistuttavalla, hyvin alkusointuisella, mutta riimeihin ja trokeesäkeisiin nojaavalla mitalla kirjoitettuna (VKK: Menn1699). Melko samankaltaisella alkusointuisella ja riimillisellä, tavunpituuksista piittaamattomalla trokeemitalla kirjoitti myös Tammelan kirkkoherra ja aiempi Turun tuomiokirkon kappalainen Laurentius Petri Ajan tieto -kronikkansa jo vuonna 1658 (VKK: LPet1658). On vaikea ajatella, että kansan parissa jo käytöstä jäämässä oleva tai kirkonmiesten pakanalliseksi uhkaksi kokema runomitta olisi sovelluksinakaan käynyt näihin tehtäviin. 


\section{0-LUVUN KIRJALLISET KALEVALAMITAN SOVELLUKSET}

Kun maallisia kirjallisia runoja alettiin 1600-luvun myötä painaa, oli kalevalamitta osa myös niiden keinovaroja. Kuninkaiden kruunajaisiin ja merkkipäiville, ystävien opinnäytteisiin ja suosijoiden häihin, syntymäpäiville ja hautajaisiin laadittiin pieniä runopainatteita. On ajateltu, että oppineet kyllä tekivät parhaansa, mutta muutamaa poikkeusta lukuun ottamatta he eivät osanneet tuottaa kunnollista runoa. On oletettu, että klassinen kalevalamitta oli se muoto, jota kohti he pyrkivät tai jota kohti heidän olisi tullut pyrkiä. (Esim. Melander 1928; Sarajas 1956; Suomi 1963b). On kuitenkin syytä kysyä, missä määrin hybridiset, kalevalamitan ja riimillisten runomittojen kirjallisia ja suullisia piirteitä yhdistävät muodot olivat tarkoituksellisia: oppineiden pyrkimyksenä ei useinkaan näytä olleen tuottaa suullisen kaltaista mittaa vaan osoittaa eri tavoin oppineisuuttaan, paikallisuuttaan ja muunkielisten runomuotojen tuntemustaan (ks. myös Laitinen 2006, 53). 1600-luvun suomenkielisen runouden taustaksi on hahmoteltavissa Ruotsin suurvalta-aika, Turun akatemian ja kirjapainon perustaminen, barokin ajan runoihanteet, luterilaisen puhdasoppisuuden kausi ja tarve mahtipontiseen valtakunnan historian kirjoitukseen, jonka lähteiksi kelpasi myös kansanperinne. (Joutsivuo 2010; Riikonen 1999; Sarajas 1956, 29-111.) Kirjallisten runojen joukkoon kuuluu monenlaisia lajeja ja muotoja eri kielillä: knittelimittaa, riimillisiä mittoja, antiikin mittoja, kalevalamittaa ja näiden erilaisia sekoituksia (Melander 1928).

Ensimmäisen suomenkielisen, sangen väljän oloista, alkusoinnutonta, riimillistä knittelimittaa noudattavan säilyneen onnittelurunon kirjoitti suomalainen Valentinus Thomae vuonna 1589 kuningas Sigismundin juhlakirjaan Vilnassa. Tässä runossa ei kalevalamitan piirteitä ole nähtävissä. Toinen säilynyt runo on Olaus Georgii Suomalaisen onnitteluruno Turun rehtorin häihin vuonna 1609. (Suomi 1963a, 260-261.)

\footnotetext{
Hoy, hoy| suosi|nen Su|kuni!

Quing niin| vnhod|hat U|kuni?

Fyiffyi| Poutack| vaiko| halla

Mick on| olla| Suomen|-maalla

Ettei| siellä| löytä| enää

Tervett| kättä| taikka| nenää [...]

(Suomi 1963a, 261.)
}

Runo rakentuu riimin yhdistämille, kalevalamitan rytmiä noudattaville parisäkeille. Murrelma- ja trokeesäkeitä sekä alkusointua esiintyy, mutta niin myös lyhyttä pääpainollista tavua painollisessa asemassa. Syntaksi on kaukana suullisen kalevalamitan tyylistä.

Ensimmäisen kokonaisen raamatunsuomennoksen alkulehdille painettiin vuonna 1642 omistusruno kuningatar Kristiinalle:

Christi|na suu|risu|cuinen

Tytär| corki|an $\mathrm{Cu} \mid$ ningan $^{\circ}$

Ruodzin Dro|tingi| woima|linen

Cuwas| täss olsote|tan. 


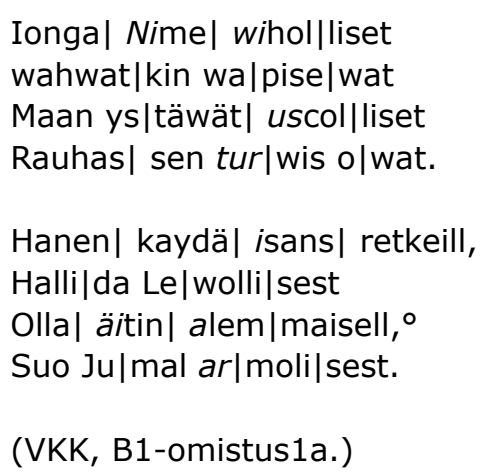

Omistusrunossa on sekä trokeesäkeitä että kalevalamitan kaltaisia murrelmasäkeitä, tavupainon poikkeamia, säännöllinen riimi (abab), kolme nelisäkeistä säkeistöä ja muutamassa säkeessä alkusointua. Säkeistöt on painettu Raamatun loistopainoksen korealle kuningattaren kuvan sisältävälle sivulle kaksi säettä rinnan, latinankielisen runon viereen (Biblia 1642, esilehti). Joka toinen säe on yleensä kahdeksan-, joka toinen seitsenasemainen. Lauserakenne on hyvin kaukana suullisesta kalevalamitasta. Runo edustaa yhdenlaista hybridimuotoa säkeistömuodon, riimin, kalevalamitan ja kirjallisen runon välillä.

Kenties tunnetuin 1600-luvun suomenkielisistä oppineista runoista on turkulaisen Ericus (Erik) Justanderin vuonna 1654 painattama kalevalamittainen onnitteluruno Kuningas Kaarle X Kustaan häihin. Runo oli osa koreasti painettua onnittelurunojen vihkosta. Sen latinankielinen johdantoteksti oli painettu kruunun ja valtakunnanomenan muotoon. Suurin osa vihkosen runoista oli latinaksi. (Melander 1928, 8-16.) Suomenkielisen runonsa Justander nimesi suomalais-hämäläisen muinaisrunon imitaatioksi (Imitatio Antiquorum Tavvast-Finnonicorum Runorum):

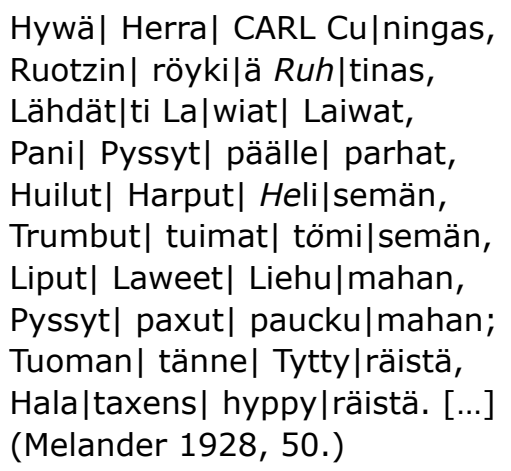

On vaikea sanoa, pitäisikö tämänkään runon mittaa kutsua enää kalevalamitaksi. Runon 31 säkeestä 20 koostuu pelkästään keskenään alkusointuisista sanoista, kun taas kansanomaiselle kalevalamitalle on ominaista maltillisempi alkusoinnun käyttö. Riimi yhdistää jokaisen säeparin, kun taas klassisessa kalevalamitassa riimiä ei ole. Jokaisessa säkeessä on kahdeksan tavua, kun taas klassisessa kalevalamitassa tavuja voi olla vaihdellen kahdeksasta kymmeneen säettä kohden. Tavut on sijoitettu runoon paikoin niiden pituuksista välittämättä, vaikka joukossa on myös tyylipuhtaita murrelmasäkeitä. Kalevalamittaisen runon trokeesäkeet 
puolittavasta kesuurasta tai pitkien sanojen sijoittamisesta säkeen loppuun ei ole piitattu ("Jotca| Juma|lalle kelpais"). Suullisen kalevalamitan pohjalta on luotu aivan oma kirjallisen runon lajinsa.

Vaikka Melander katsoo Justanderin käyttämän mitan olleen sama kuin Hemminki Maskulaisen virsissä, on kyseessä tarkemmin katsottaessa kaksi aivan erilaista muotoa (Melander 1928, 14). Riimiä ja alkusointua käyttivät kyllä molemmat, ja suhde tavujen painoihin ja pituuksiin oli kummallakin väljä. Maskulaisella runojen pohjarakenne oli kuitenkin yleensä jambinen ja säkeistöllinen, Justanderilla trokeinen ja säkeistötön. Säkeiden tavumäärät ja kalevalamittaisten piirteiden käyttötavat vaihtelivat Maskulaisella paljon, Justanderilla taas tavumäärät ja alkusointurakenteet olivat hyvin vakioituja.

Siinä missä Maskulainen kirjoitti virtensä suomenkielisen kansan laulettaviksi, laati Justander onnittelurunonsa suomen- ja ruotsinkielisten oppineiden ja eliitin jäsenten luettavaksi. Toini Melander huomauttaa, että Justanderin runon muoto noudattaa tarkkaan sekä 1600-luvun kieliopeissa ilmaistuja käsityksiä suomalaisen runouden mitasta että yleisempiä eurooppalaisia barokin ajan muotivirtauksia. "Muinaisrunot" olivat tulleet muotiin oppineessa käytössä koko valtakunnassa, mutta samalla runomittojen säännöt olivat alkaneet tiukentua. (Melander 1929, 13-14; ks. myös Riikonen 1999, 64.) "Näyttää melkein siltä, kuin olisi Justander tervehdystä laatiessaan enemmän tarkoittanut sitä silmin nähtäväksi kuin korvin kuultavaksi," toteaa Melander (Melander 1929, 13). Mitta tiheine alkusointuineen, riimeineen ja tasaisine tavulukuineen näytti hyvin säännölliseltä myös kieltä taitamattoman yleisön silmin.

Oppineiden runojen kirjo on liian laaja pelkistettäväksi tässä. Kalevalamitan kaltaisten runojen joukossa on kuitenkin hahmotettavissa perusjako yhtäältä kalevalamittaa ja riimiä yhdistävien, usein trokeesäkeisiin ja sanapainoihin nojaavien, toisaalta suullisenkaltaista klassista kalevalamittaa käyttävien runojen välillä. Klassista, riimitöntä kalevalamittaa alkoi oppineiden runoihin ilmestyä 1600-luvun jälkipuoliskolla (Melander 1928, 30, 69). On todettu, että jako on vahvasti sidoksissa kirjoittajien kotiseutuun. Läntisimmästä Suomesta kotoisin olevat kirjoittajat käyttivät yleensä riimillistä, tavun pituuksista piittaamatonta, usein tavuluvultaan säännöllistettyä ja allitteraatiota ylenpalttisesti käyttävää kalevalamitan muunnelmaa, kun taas etenkin Pohjois-Pohjanmaalta ja Kajaanista kotoisin olevat pappismiehet suosivat klassista kalevalamittaa. (Sarajas 1956, 56-58.)

Pohjoisten oppineiden kotiseuduilla suullinen kalevalamitta vastasi klassista muotoa 1800- ja jopa 1900-luvulle asti. Näillä seuduin sivistyneistö selvästi jakoi osan kansankulttuurista - muualta kuin suullisesta perinteestä ei klassinen kalevalamitta voinut 1600-Iuvun loppupuolella nousta kirjoitetun runon piiriin. Länsisuomalaisten oppineiden suhteen taas on ajateltu, että heidän runonsa osoittavat, että he eivät tunteneet kunnolla kansanomaista suullista runoa, koska sitä ei heidän kotiseuduillaan enää käytetty (esim. Sarajas 1956, 40, 56).

Länsisuomalaisen oppineen kalevalamitan piirteille on kuitenkin kaksi muutakin mahdollista selitysmallia. Näyttää siltä, että oppineiston piirissä suullisen runon 
piirteitä käytettiin tietoisesti erilaisten uusien, aikakauden yleisempiä ihanteita noudattavien kirjallisten lajien rakennusaineina. Tältä kannalta katsottuna oppineen runomitan piirteet ovat osoitus suullisen mitan piirteiden kekseliäästä soveltamisesta erilaisiin lajeihin ja kirjallisiin käyttökonteksteihin, eivät kansanrunon huonosta tuntemuksesta. Toisaalta voi myös olla, että uuden ajan alun länsisuomalainen suullinen runous oli paikoin melko kaukanakin klassisesta kalevalamitasta. Tämä tarkoittaisi sitä, että oppineet loivat kirjalliset muotonsa osin jo sanapainoille taipuvan tai niistä piittaamattoman, säkeiltään lyhentyneen tai kenties jo paikoin riimiäkin soveltavan suullisen kalevalamitan pohjalta.

\section{RUNOMITAN KUVAUKSET}

Ensimmäinen kuvaus kalevalamittaisesta runosta sisältyy ruotsalaisen Andreas Bureuksen laatimaan Ruotsin kartastoon vuodelta 1626 (Bure 1626). Hänen mukaansa suomalainen mitta ei perustunut riimille kuten muilla kansoilla vaan alkusoinnulle. Säkeet hän kuvasi kahdeksantavuisiksi. Ilmeisesti kuvaus perustui itäsuomalaiseen suulliseen runouteen. Se on täysin sopusoinnussa klassisen kalevalamitan kanssa. Bureuksen kuvauksen lainasi esimerkiksi Erik Schroderus vuonna 1637 ensimmäisen suomalais-ruotsalaisen sanakirjansa esipuheeseen. (Sarajas 1956, 31-32.)

Toisenlainen, usein virheelliseksi tulkittu suomalaisen runon kuvaustraditio sai alkunsa 1600-luvun puolivälissä Turussa. Ruotsista kotoisin ollut Turun akatemian professori Aeschillus Petraeus kirjoitti paikallisten pappien avustuksella suomen kielen alkeisoppikirjan Linguae Finnicae Brevis Institutio, jota pitkään pidettiin ensimmäisenä suomen kielioppina, ja joka toimi esikuvana muille teoksille (ks. Lauerma 2012). Petraeus kuvaa parilla sanalla riimin suomalaiselle runolle välttämättömäksi ja alkusoinnun sen vaihdellen esiintyväksi erityispiirteeksi. Riimien sepittäminen on hänen mukaansa kohtuullisen helppoa, koska sanoja saa lyhentää. Tavun laajuudesta ei Petraeuksen mukaan runomitassa välitetä. (Petraeus 1968 [1649], 65-68; Sarajas 1956, 38-41.)

Vaikka suomalaisen runon mitan kuvaus on lyhyt ja väljä, on Petraeuksen esimerkkikokoelma sangen kattava otos siihenastista suomenkielistä runoa. Ensimmäinen esimerkki on yksi Hemminki Maskulaisen eniten kalevalamittaa muistuttavista virsistä, hänen itse psalmista 130 sepittämänsä pääosin trokeinen (+---+-+), riimillinen (aabccbddee) ja vahvan alkusointuinen virsi (Kurvinen 1929, 325-326).

YNnä| yxil yhte|ys, käski|näinen| racka|us, Välill| veljes|ten e|lon: Ynnä| yhdes| asu|a, IIman| yhtän| hasu|a, Velje|xit o|mall, eh/doll: Ihanamb| on mie|list i lloo, ${ }^{\circ}$ Suloilsemb suo|tuist elloo, Caickein| callein ca|luu ja|loo . etc. (Petraeus 1968 [1649], 65.) 
Petraeuksen toinen esimerkki on Finnon sepittämä, Lutherin esikuvaa ja jambista (-+-+-+-(+)), riimillistä (ababccd) säkeistörakennetta noudattava virsi psalmista 133 (ks. Kurvinen 1929, 266). Esimerkiksi valitussa säkeistössä on alkusointua Finnon virreksi poikkeuksellisen paljon (kolme säettä seitsemästä), vaikka Petraeus asettaakin virren edustamaan alkusoinnulle perustumatonta runoa. Osa säkeistä on luettavissa puhtaan trokeisiksi: "Ava| corvas|, äänen| cuule". (Petraeus 1986 [1649], 65-66.)

Virsien jälkeen Petraeus esittelee kymmenen arvoitusta, jotka pääosin perustuvat selkeälle kalevalamitalle, vaikka joskus sanat esiintyvät klassista mittaa lyhyemmissä muodoissa ("Elä|vä[inen]| alla| ähky"). Muutamin paikoin kieliopilliset muodot tai sanavalinnat tekevät riiminkaltaisen vaikutelman ("Lyhykäinen lylleröinen, tasapäinen talleroinen, carjan corvesta cocopi"). Osion päättävät jo Agricolalla esiintyneet sananlasku ja eläinten kantamisaikoja listaava hokema. Sananlaskussa sanajärjestystä on ilmeisesti muokattu riimin aikaansaamiseksi, jolloin kalevalamittainen pohjarakenne on kadonnut: "Päiwän sappi satehexi, kuun kehä poudixi". (Petraeus 1968 [1649], 66-70.)

Alkusointu ja riimi olivat Petraeukselle keskeisimmät, vaihdellen esiintyvät suomalaisen runon tunnuspiirteet, ja myös runot on valittu tätä ajatusta tukemaan. Alkusointua vieroneelta Finnolta on valittu mahdollisimman alkusointuinen esimerkki, Hemminki Maskulaiselta mahdollisimman kalevalamitankaltainen, trokeinen esimerkki ja arvoituksista on valikoitu kalevalamittaiset, mutta edes osin riimiä mukailevat esimerkit. Agricolalta on osattu poimia hänen ainoat kalevalamitankaltaiset tekstinsä. Vaikka Petraeus ei puutu suomenkielisen runon tarkempaan säerakenteeseen, on esimerkeiksi valittu ainoastaan seitsemästä yhdeksään tavua käsittäviä säkeitä.

Ajan kieliopeissa tekstiesimerkit ovat yleensä Raamatusta (Lauerma 2012; ks. Martinius 1968 [1689]; Petraeus 1968 [1649]). Tähän linjaan sopi keskeisten esimerkkien valinta psalmivirsistä. Yllättävää on ennemminkin se, että Petraeus valitsi esimerkkejä myös suullisesta perinteestä, ja kautta linjan hän valitsi alkusoinnun ja tavuluvun osalta mahdollisimman kalevalamitan kaltaisia tekstejä. Jos hän todella olisi kansanrunoa ja etenkin loitsuja vieroneen piispa Isaacus Rothoviuksen hengessä halunnut kuvauksellaan ja esimerkeillään häivyttää oikean kalevalamitan näkyvistä (Sarajas 1956, 38-41), olisi valittavaksi riittänyt puhtaan jambisia ja täysin alkusoinnuttomia toisintoja. Kuvaus päinvastoin osoittaakin, että alkusointu oli 1600-luvun puolivälissä täysin hyväksytty, jopa arvostettu virsirunouden piirre, ja ettei klassista kalevalamittaa noudattavien arvoitusten käyttämisessäkään ollut mitään sopimatonta. Kysymykseksi jää se, missä mahtoivat aikalaisille kulkea eri runomuotojen rajat.

Vuosi kieliopin ilmestymisen jälkeen Petraeuksen kollega Michael Wexionius laati laajan Ruotsin valtakunnan maantiedettä ja kulttuurioloja selvittävän teoksen Epitome descriptionis Sueciae, Gothiae, Fenningiae (Wexionius 1650). Teoksen kolmannessa osassa hän kuvaa Petraeusta mukaillen suomalaisen runon riimilliseksi ja alkusointuiseksi. Esimerkkinä Wexioniuksella on edellä käsitellyn 
Kati Kallio: Kalevalamitta oppineiden käytössä uuden ajan alun Suomessa

Melartopaeuksen Piae Cantionesista virsikirjaan kääntämän Lauluja nyt laskecam -virren trokeiset, miltei kalevalamittaiset säkeet (+-+-+-+):

Pojat| parhat| pauhat|kat,

Neitzet| nuoret| iloit|kat,

Vanhat| vahvast| veisat|kat

(Wexionius 1650, 3. nide, jakso 14; vrt. VKK, Hemm1605-135:3-L8b.)

Uutena tietona Wexionius kertoo heti säkeiden jälkeen, että "näillä kaikilla oli muinoin sama nuotti ja nimenä runot" ("In quibus omnibus una antiquitus melodia fuit. Dicebantur \& olim Runoi [...]", Wexionius 1650, 3. nide, jakso 14; Sarajas 1956, 42-44). Runo on uuden ajan alussa ainoastaan kalevalamittaiseen runoon liittyvä termi, ja ajatus siitä, että näillä oli vain yksi sävelmä, periytyi 1800-luvulle asti (Laitinen 2006, 52). Wexioniuksen kuvaus kertoo kuitenkin epäsuorasti, että hän katsoi "runoja" laulettavan omana aikanaan jo useammilla sävelmillä. Jos kuvauksen ottaa tosissaan, se myös kertoo, että joidenkin alkusointuisten neli-iskuisten virsien tulkittiin 1600-luvulla liittyvän vanhan suomalaisen suullisen runon jatkumoon (Krohn 1862, 39). Mahdollisimman kalevalamitankaltaisen esimerkin valinta virsikirjan 242 virren joukosta osoittaa osaltaan Wexioniukselta tai hänen apulaisiltaan suurta virsirunouden asiantuntemusta.

Etenkin Petraeuksen runomittakuvausta on pidetty väärinkäsityksenä tai tahallisena vääristelynä. On ajateltu, että ruotsia äidinkielenään puhuneet, kaupungissa oleskelleet oppineet eivät yksinkertaisesti tunteneet kunnolla kansanrunoutta tai halusivat häivyttää sen näkyvistä. (Esim. Suomi 1963b, 264-265; Sarajas 1956, 39-43; ks. myös Hautala 1954, 38-39). Tämä on kuitenkin ylitulkinta. Kirjoittajat eivät missään sano haluavansa kuvata ainoastaan suomalaista kansanrunoa tai muinaisrunoa. Petraeuksen kuvaus kattaa esimerkkeineen lähes kaiken 1600-luvulla läntisessä Suomessa käytetyn tuntemamme runouden. Päinvastoin yllättävää on, kuinka paljon kumpikin kuvaaja antaa esimerkkivalintojensa kautta painoa kalevalamittaiselle runolle tai runouden kalevalamitankaltaisille piirteille.

Alkusointu on ainoa tekijä, joka yhdistää kaikki kuvaukset Bureuksesta (1626) Porthaniin (1983 [1766-1778]) asti riippumatta siitä, mihin aineistoon he kuvauksensa nojaavat. Wexionius mainitsi, että suomalaiset eivät oikein edes tunnista laulua lauluksi, jos siinä ei ole alkusointua (ks. Krohn 1862; Wexionius 1650, 3. nide, jakso 14). Se oli selvästi suomenkielisen runouden huomiota herättävin keskeispiirre. Riimi oli länsisuomalaisissa kuvauksissa yhtä keskeinen ainakin 1730-luvulle asti (Sarajas 1956, 99, 131-132). Tavujen laajuuksista ei suomalaisessa runoudessa kuvausten mukaan piitattu. Runosäkeiden rakenteiden tarkempi teoreettinen kuvaus ei tosin ollut edes mahdollista. Virsirunous todellakin rakentui tavun laajuuksien ja pituuksien osalta hyvin vaihdellen ja usein väljästi. Klassisen kalevalamitan tavusäännöt puolestaan ovat länsimaisen klassisen runomittaopin kannalta käsittämättömät, ja ne kuvattiin osuvasti vasta 1800-luvulla (Kuusi 1994, 42). Lisäksi kalevalamitta eli uuden ajan alussa mitä moninaisimpina suullisina ja kirjallisina sovelluksina. Muotojen kirjon asetti ruotuun vasta Porthan 1700-luvun lopulla määrittämällä tarkemmin, mitä kalevalamitta oli ja mitä se ei ollut (Porthan 
Kati Kallio: Kalevalamitta oppineiden käytössä uuden ajan alun Suomessa

1983, 39-53). Porthanista alkanut mitan suppeamman määrittelyn traditio on osaltaan sulkenut silmät muutamilta rytmisesti rakentuneilta teksteiltä.

\section{KUNINKAALLISET TITULATUURAT JA MUUT NIMEÄMISET}

Perinteistä käsitystä kalevalamitan rajoista ja mittaan liittyneistä assosiaatioista liikuttaa osaltaan se tapa, jolla Ruotsin valtakunnan kuningas nimesi itsensä suomenkielisissä kirjeissään ja asetuksissaan (titulatuurat) ja jolla hänet ja muita merkkihenkilöitä erilaisissa omistuskirjoituksissa ja muissa teksteissä paikoin nimettiin (dedikaatiot).

Ensimmäinen suomenkielinen kuninkaan titulatuuran muotoilu on Agricolan Psalttarin esipuheessa vuonna 1551 (Agricola III, 198), ja virallista kaavaa toistaa Kustaa Vaasan ensimmäinen tunnettu suomenkielinen kirje vuodelta 1555 Savonlinnan asukkaille: "MEe Gustaff Jwmalan Armon Kansa, Rodzin Götin Wendin etc Kuningas" (Grotenfelt 1912, 5).

Kuningas Juhana III kirjeessä vuonna 1584 titulatuuran kirjoitettu muoto pidentyy Suomenmaalla ja uusilla valloitusalueilla. Lauserakenteita, välimerkkejä ja seuraavan vuosisadan muotoiluja mukaillen etenkin titulatuuran alkuosa on mahdollista tulkita neli-iskuisiksi jaksoiksi. Kuninkaan nimestä koostuvaa ensimmäistä säettä rytmisyys ei koske.

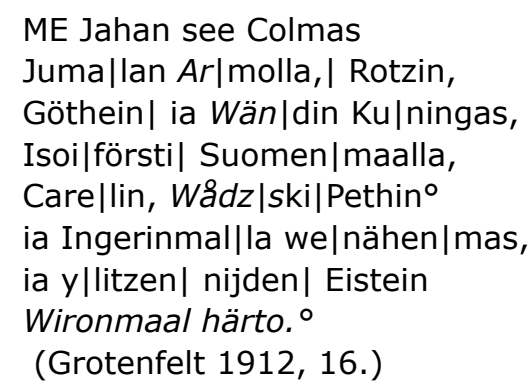

"Isoiförsti Suomenmaalla" on puhtaan kalevalamittainen muotoilu. Toinen ja kolmas säe kävisivät mittavirheisistä säkeistä, loput tulkinnanvaraisemmin, viimeinen ei mitenkään. "Suomenmaa" on muodossa tai toisessa todennäköisesti liittynyt jo Kustaa Vaasan titulatuuran etc-maininnan taakse jääneisiin, mahdollisesti ääneen luettaessa täydennettyihin osuuksiin.

Juhanan veljellä Kaarle-herttualla muotoilu poikkesi perinteisestä, luultavasti omaan taustaan ja vallanperimyskiistoihin liittyvistä syistä, eikä sitä nähdäkseni yritetty rakentaa rytmiseen muotoon (Grotenfelt 1912, 22). Kaarle-herttuan pojan, Kustaa Adolfin, kohdalla tapahtui selkein muutos. Vuonna 1628 titulatuuran muotoilu on säkeiden pilkutusta myöten neli-iskuinen ja kattaa valloitusmaatkin:

Me Gustaff Adolph

Juma|lan ar|mosta| Ruotzin, Göthin| ia Wen|din, Cu|ningas, Suri|försti |Suomen |Maalle, Eestin| maalle| ja Ca|relin, 
Kati Kallio: Kalevalamitta oppineiden käytössä uuden ajan alun Suomessa

[http://www.elore.fi/arkisto/1_15/kallio.pdf]

Herra| Inger|mannin| maalle

(VKK, AHF-1628-74.)

Tämä on tyylipuhtain versio rytmisistä kuningastitulatuurista kautta aikain. Säkeet noudattavat kuninkaan nimeä ja perinteisimmän alkuosion kahta tavupainojen rikkoa lukuun ottamatta täysin klassisen kalevalamitan rytmiä. Mukana on suulliselle runolle ominaisia murrelmasäkeitäkin. Alkusointua ei kuitenkaan esiinny Suomea koskevaa säettä lukuun ottamatta, ja syntaksi poikkeaa klassisesta kalevalamitasta.

Kustaa Adolfia seurannut kuningatar Kristiina - siis hänen kirjurinsa - muokkasi muotoilua vaihtelevin tavoin kuningattarelle sopivaksi. Tekijä on pitänyt säkeiden rytmin ja tavumäärän vakaana tavupainojen sijoittumisen kustannuksella.

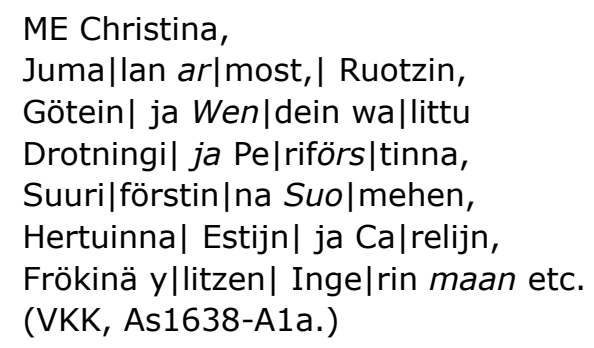

Myöhemmissä Kristiinan ja hänen seuraajiensa käyttämissä formuloissa mitta murtuu ja jää käytöstä kokonaan etenkin loppuosan pitkissä Puolan ja Saksan valloitusalueiden luetteloissa: "[...] Hertiginna Wirois, Carelis, Bremis, Verdis, Statinas, Pommeris, Cassubis ja Wendis, Förstinna Rugis, Frowa Ingerinmaalla ja Wissmaris" (VKK, As1652-A1a). Pysyvästi titulatuuriin jää ainoastaan jo Kustaa Vaasan käytössä ollut perinteinen, suoraan ruotsin kielestä käännetty alku: "Jumalan armosta Ruotsin, Göötein ja Vendein kuningas" (Grotenfelt 1912, esim. 193, 287). Suomenkielisten kuningastitulatuurien selkeä rytmisyys näyttää olevan hetkellinen Ruotsin suurvalta-ajan ilmiö.

Kalevalamitakaltaisia rytmejä on luettavissa muissakin aikakauden teksteissä. Ljungo Thomae omisti Ruotsin maanlain käännöksensä vuonna 1601 kuninkaalle proosapuhutteluin, mutta viittasi itseensä proosan keskellä rytmisesti kertoen suomennoksen tehdyksi

Suoma|laisten| tarpe|hexi.

Liungi| Thoma|han po|ialta,

Cala Jolen kyr|ko her|ralta.

(VKK, Lju1601-7).

Kaksi ensimmäistä säettä ovat klassista kalevalamittaa, kolmas mittavirheinen murrelmasäe. Hemminki Maskulaisen tapa käyttää alkusointua vuoden 1616 Piae Cantiones -suomennoksensa omistuspuheessa ei ole yllätys. Alkusointua viljelevän rytmisen proosan keskelle sijoittuva suosijan nimi asettuu kaikista selvimmin neli-iskuiseen rytmiin:

Hendrich Hor|nille| Canckai|sista

Ruodzin Ku|ningan |Marschal|killen,

Vennan |ja Hes|lan Her|ralle [...] (Grotenfelt 1912, 64) 
Kati Kallio: Kalevalamitta oppineiden käytössä uuden ajan alun Suomessa

[http://www.elore.fi/arkisto/1_15/kallio.pdf]

Kaksi ensimmäistä rytmistä säettä ovat tässäkin kalevalamittaa, kolmas mittavirheinen murrelmasäe. Vuonna 1657 samaan Kankaisten Hornien sukuun kuulunut Gustav Horn nimeää itsensä pääosin suullisen runon rytmiin taipuvalla muodolla

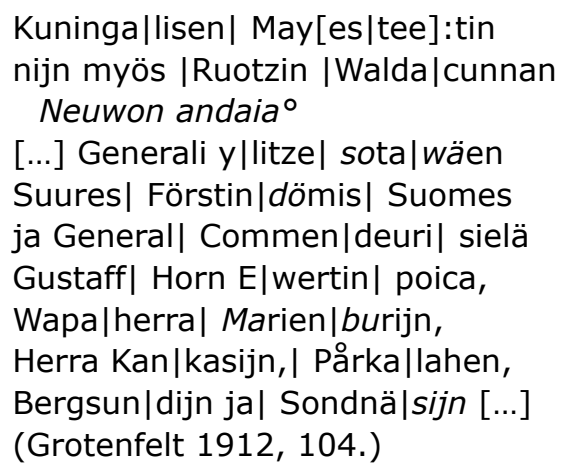

Säkeistä viisi kävisi tavurakenteensa puolesta moitteettomista klassisen kalevalamittaisista säkeistä, vaikka monissa säkeistä tavujen pituuksista ei piitata. Alkusointua ei juuri käytetä ja syntaksi poikkeaa suuresti suullisesta mitasta.

Tekstit viittaavat siihen, että kalevalamitakaltainen rytmi koettiin suomen kielen piirissä relevantiksi muodollisten tilanteiden ja tekstien rekisteriksi jo ennen varsinaista antikviteetti-innostusta. Tekstien kirjo kattaa kuningastitulatuuria virallisissa kirjeissä ja asetuksissa, omistusrunon, lainsuomennoksen sekä kenraalin käskykirjeen. Rytmiä ovat käyttäneet kuninkaan suomenkielisten kirjureiden ohella sekä länsisuomalaiset suomenkieliset oppineet kirkonmiehet (Ljungo Thomae, Hemminki Maskulainen) että aateliset (Gustav Horn).

On selvää, että etenkin kuninkaan titulatuuran perinteinen alkuosa on muodostunut ruotsinkielistä versiota lähes suoraan suomentaen, mikä ei anna juuri tilaa poeettiselle muokkaamiselle. On myös selvää, että teksteissä ei ole pyritty alkusoinnun tai suulliselle mitalle ominaisten lauserakenteiden käyttöön, vaan ainoastaan sovittamaan sisältöä tiettyyn rytmiin. Poikkeamia tavunlaajuuksissa sallittiin runsaastikin. Punoutuminen osaksi proosatekstejä, variaatio, käytetyn mitan epämääräisyys, alkusoinnun ja riimin puute sekä suullisesta runosta poikkeava syntaksi ovat luultavasti vaikuttaneet siihen, että tekstejä ei ole edes tunnistettu runorytmisiksi. Niistä tulee mieleen Porthanin kuvaus siitä, miten jotkut hänen aikansa talonpojat "sekoittavat säkeitä miltei kaikkeen puheeseensa ja pyrkivät pukemaan varsinkin vakavammat esityksensä jonkinlaiseen runomuotoon" (Porthan 1983[1766-1778], 70). Painokas, rituaalinen tai virallinen kieli mukaili miltei huomaamattomasti, ehkä tiedostamattomastikin kalevalamitan rytmejä.

\section{MITÄ OLI LÄNSISUOMALAINEN SUULLINEN RUNOUS?}

Yleensä perinteen- ja kirjallisuudentutkimuksen piirissä on ajateltu, että suomenkieliset oppineet elivät jo 1500-luvulla selkeästi erillään kansankulttuurista. Perusoletus on, että länsisuomalaisilla oppineilla, etenkään turkulaisilla, ei ollut juuri mahdollisuuksia kuulla kalevalamittaista suullista runoa (esim. Sarajas 1956, 40, 
54, 84; Suomi 1963a, 247, 258; Suomi 1963b, 264-265, 270). Tulkinnoissa on siten ollut kysymys lähinnä siitä, kuinka paljon oppineet tunsivat itselleen etäistä suullista kansankulttuuria ja paljonko he sitä vääristelivät tai häivyttivät. Jos käännetään oletus toisin päin, ja pidetään edes mahdollisena, että Turun seudulla oli suomenkielistä lauluja ja että oppineet tunsivat ja jopa käyttivät kotiseutujensa suullista runoutta, muuttuu kuva sekä oppineista että kansankulttuurista.

Daniel Juslenius kirjoittaa vuonna 1700 Turun seutua ylistävässä opinnäytetyössään Aboa vetus et nova kalevalamittaista paikallista kosinta-aiheista runoa käsitellessään, että "maalaisväestön suullisessa perinteessä tavataan paljon tällaisia muinaisista uroteoista kertovia lauluja" (Juslenius 1987 [1900], 75). Maininta on pelkkä sivumennen esitetty toteamus: Jusleniuksen varsinainen argumentti keskittyy kansanrunojen arvoon historiankirjoituksen lähteinä. Hänen käyttämänsä muutamat esimerkkisäkeet ovat pääosin klassista kalevalamittaa murrelmasäkeineen, mutta kahdeksasta säkeestä kahdessa on lyhyt pääpainollinen tavu runojalan nousussa. (Juslenius 1987 [1700], 75-76; Harvilahti 2012, 391-393; Siikala 2012, 30-31). Vaikka kirja on akateeminen kotiseudun ylistys ja siten monin paikoin idealisointi, ei mikään tunnettu lähdeaineisto myöskään kiistä Jusleniuksen väitettä siitä, että 1600- ja 1700-luvun vaihteen Turun seudulla maalaiset lauloivat kalevalamittaisia runoja. Ajatus on sopusoinnussa myös aikakauden kalevalamittaisten kansalle suunnattujen painettujen pitkien tekstien kanssa (esim. Ilo-laulu Jesuxelle, Huonen-Speili, Ajan Tieto). Jos rintamaiden lukutaitoisin kansa ei olisi enää piitannut kalevalamitasta, ei tekstien julkaisemisessa olisi ollut paljonkaan mieltä. On silti syytä kysyä, mitä kaikkea mahtoi tuonaikainen suullinen kansanruno olla.

Kalevalamittaisissa Länsi-Suomesta lähinnä 1700-luvulta lähtien tallennetuissa suullisissa runoissa on yleistä klassisen mitan sääntöjä väljempi lyhyiden painollisten tavujen käsittely. Heikki Laitinen on pohtinut, voisiko tämä piirre olla myöhäisen kehityskulun sijasta läntisen kalevalamittaisen runon vanha piirre (Laitinen 2006 , 38). Kuten edellä on huomattu, sekä lyhyiden että usein pitkienkin painollisten tavujen käsittelyn väljyys lyö läpi koko uuden ajan alun kirjallisen ja suullis-kirjallisen lajien ja muotojen kirjon Agricolasta alkaen, milloin vahvempana, milloin heikompana. Sen on yleensä ajateltu kertovan kansanrunouden huonosta tuntemuksesta, jambisten mittojen vaikeudesta tai silkoista väärinkäsityksistä. Entä jos se olisikin vain länsisuomalaiselle aikalaisrunoudelle tyypillinen, yleisesti hyväksytty piirre, jota saattoi esiintyä jopa kansanrunouden arkaaisimmissakin muodoissa jonkin verran? Siten kyseinen ominaisuus oppineiden runoissa ei kertoisikaan erosta kansan laulutapoihin, vaan nimenomaan yhteydestä paikallisen suullisen laulun tyyleihin.

Läntisille suullisille runoille on tyypillistä suuri muotojen kirjo. Alueelta etenkin 1800-luvulla tallennettujen pidempien runojen joukossa on samoistakin teemoista niin klassisen kalevalamittaisia, mitaltaan eri tavoin väljentyneitä kuin riimirakenteiden tai sanapainopohjaisuuden suuntaan kallistuvia ja mitattomiakin tekstejä (ks. esim. SKVR VIII 50-105, 319-331; 1248-1263). Henrik Florinus julkaisi vuonna 1702 Länsi-Suomesta pääosin 1600-luvulla tallennettujen sananlaskujen laajan kokoelman. Joukossa on sekä klassisen kalevalamittaisia, Agricolan julkaise- 
man sananlaskun tavoin typistyneitä ("Arca hengens pitä" - arka henkensä pitävi) että proosamuotoisia tekstejä (Florinus 1702; VKK Flor1702-A1b).

Riimillisen ja säkeistöllisen laulun ajatellaan yleensä alkaneen läntisillä rannikkoalueilla kehittyä viimeistään 1600-luvulta lähtien tai ehkä jo hieman ennen reformaatiota (Leino 1994, 56-57; Asplund 2006). Ensimmäiset riimilliset pilkkalaulut löytyvät 1600-luvun tuomiokirjoista (Asplund 2006, 109-112). On ajateltu, että kehitys on tapahtunut virsilaulun mallien innoittamana (Asplund 2006, 117). Heikki Laitinen kuitenkin näyttää, että säkeistöllisen kansanlaulun rakenteet ovat monissa kohdin etäällä virsien rakenteista (Laitinen 2003, 205-282). Nähdäkseni onkin syytä myös kysyä, olisiko malleja voitu ottaa myös muunkielisistä suullisen laulun lajeista aikaisemminkin (ks. myös Häkkinen 2013). Erilaisia säkeistöllisiä, riimillisiä tai sanapainoihin perustuvia kokeiluita on teoriassa voitu tehdä skandinaavisten ja germaanisten kulttuurien kanssa vuorovaikutuksessa olleilla rannikkoseuduilla (Leskelä, (tulossa)) jo siitä lähtien, kun riimi viimeistään 1100-luvuilla alkoi olla osa näiden kielien suullista runoutta (Gasparov 1996). Myös latinankielisiä riimillisiä ja säkeistöllisiä lauluja (ks. Page 2010) on Länsi-Suomen alueella kuultu laajalti viimeistään 1200-luvulta lähtien, todennäköisesti aikaisemminkin (Pirinen 1991).

On mahdollista, että riimillisillä tai uudenlaisiin painojärjestelmiin perustuvilla suomenkielisillä laulukielillä olisi keskiaikaisiakin juuria. Ne ovat muodostaneet vaihtelevia hybridimuotoja kalevalamitan kanssa - ainakin oppineiden käytössä viimeistään 1500-luvun lopulla. Varsinaisen suullisen kalevalamitankaan rajat eivät ole reformaatioajan Länsi-Suomessa vastanneet klassisen kalevalamitan rajoja. Agricolan julkaisemat kaksi kalevalamittaan pohjautuvaa tekstiä typistyneine sanoineen ovat kenties olleet mitä osuvin näyte hänen aikansa länsisuomalaisesta suullisesta perinteestä. Erilaisten muotojen rinnakkaiselon aika kuitenkin on pitkä. Tallennettu aineisto osoittaa kalevalamitan olleen tiettyjen lajien yhteydessä yhä 1900-luvun alkupuoliskollakin käytössä myös läntisessä Suomessa (SKVR).

\section{LOPUKSI}

Erilaisten suomenkielisten kirjallisten runojen lajien varhaiset kehityskulut näyttävät, että kalevalamittaa ei suljettu ulos kirjallisen tai luterilaisenkaan runon maailmasta. Sen erilaisten piirteiden käyttö ei ole poikkeus, vaan kirjallisissa lähteissä jo 1500-luvulta alkava monilajinen ja -muotoinen jatkumo, jonka puitteissa on tosin vaikea sanoa, missä milloinkin mahtoivat kulkea vanhana suomalaisena runona pidetyn muodon rajat. Suullisen mitan piirteitä virsissään pääosin vältelleiden Agricolan ja Finnon jälkeen alettiin kalevalamittaisen runon piirteitä jo 1500-luvun lopulla sulauttaa jambisiin ja riimillisiin virsiin, sen rytmiä käytettiin huomaamattomasti kuninkaallisten titulatuurien ja suomalaisten merkkihenkilöiden nimeämisen puitteissa, sen pohjalta kehitettiin alkusoinnulle ja riimille perustuva oppinut kirjallinen runous ja kaikkein tiukimman luterilaisen puhdasoppisuuden ajan lopulla kirkon piirissä julkaistiin kristinuskon keskeisimmät myyttiset tapahtumat kuvaava, suuren suosion saanut klassisen kalevalamittainen pienoiseepos.

Oppineet muokkasivat erilaisia eurooppalaisiin kirjallisiin tai puolikirjallisiin runon ja laulun lajeihin soveltuvia muotoja ja käyttivät tässä myös paikallisen suullisen 
runoperinteen piirteitä. Alkusointu ja riimi, kalevalamittainen normaalitrokee ja murrelmasäe, säkeistömuoto, parisäe ja säkeistöttömyys, jambiset mitat, säkeiden säntilliset ja varioivat tavumäärät esiintyivät mitä erilaisimpina yhdistelminä ja

variaatioina. Paikoin onkin vaikea tavoittaa vaikkapa sitä, miten aikalaiset mahtoivat hahmottaa trokeen, knittelimitan ja kalevalamitan rajat ja yhtymäkohdat. Käsitykset poetiikasta ja runon lajeista ovat selvästi myös vaihdelleet ajan myötä. Lähteiden luonteesta johtuen niputamme helposti yhteen runoja, joiden kirjon aikalaiset ovat todennäköisesti hahmottaneet useisiin eri (ala)lajeihin tai käyttökonteksteihin kuuluvina (virret, kansanrunot, oppineiden tilapäärunot). Näiden runojen poetiikassa ja merkityksissä riittäisi tekemistä laajemmillekin hankkeille.

Virsien mittaa kalevalamitasta ei tullut, vaikka alkusointua, parallelismia ja jopa mitalle tyypillisiä tavurakenteita alettiin 1500-luvun lopulla soveltaa niidenkin puitteissa. Riimi, säkeistö- ja tavurakenteet, syntaksi ja näitä piirteitä osaltaan kannattavat sävelmärakenteet erottivat virret kalevalamitasta. Kalevalamitta oli liian kaukana uuden luterilaisen virsilaulun keskeisimmistä saksan- ja ruotsinkielisistä tunnuspiirteistä, eikä nelipolvinen, säkeistötön, lauserakenteeltaankin erityinen runomuoto olisi edes teknisesti istunut moniin virsisävelmiin. Nähdäkseni se, että virsiä ei rakennettu kalevalamitan pohjalle tai kalevalamittaisiksi ei kuitenkaan tarkoita mitan kokonaisvaltaista ideologista torjuntaa, vaan lajikohtaista valintaa. Sananlaskujen ja arvoitusten julkaiseminen (1544-), alkusoinnun ja muiden suullisen runon piirteiden ottaminen myös virsien osaksi (viimeistään 1580-luvulla) sekä kalevalamitan riimillisten versioiden käyttö oppineiden tilapäärunoudessa heti ensimmäisistä lähteistä (1609-) lähtien puhuvat selkeästi täyttä torjuntaa vastaan. Kirkon näkökulmasta loitsut ja epäkristilliset runot olivat tuomittavia, mutta nämä kattoivat ainoastaan pienen osan kalevalamitan laajasta käyttöalasta ja sen kantamista assosiaatioista.

Vaikka virsiä ei rakennettu kalevalamitan kaavoihin, on silti pakko kysyä, mahtoivatko jotkut Hemminki Maskulaisen ja jopa Jacobus Finnon alkusointua ja trokeesäkeitä sisältävät, mutta nykytutkijan silmään varsinaiseksi kalevalamitaksi kelpaamattomat riimilliset ja säkeistölliset virret 1600-luvun länsisuomalaisille edustaa kalevalamittaa tai jonkinlaista kalevalamitan jatkumoa. Tuntuu ainakin ilmeiseltä, että kalevalamitankaltaisten piirteiden lisääminen virsiin teki niistä seurakuntalaisille helpommin omaksuttavia ja muistettavia, kenties myös affektiivisempia.

Vaikka oppineet kirjoittivat virret ja arkkipainatteet, tehtiin valtaosa niistä ennen kaikkea suomenkielistä, latinaa taitamatonta rahvasta ja suullista käyttöä varten. Lauluina tai laulukieliä mukailevina ne sijoittuivat suullisen ja kirjallisen välimaastoon. Samoin virallisten kirjeiden ja asetustekstien titulatuurat olivat kaikkien kieltä taitavien kuultavaksi tai käytettäväksi tarkoitettuja. Niiden suullisen runon kaltaisen rytmin voi ajatella olleen merkittävä lähinnä niitä ääneen lausuttaessa tai kenties resitoitaessakin. Sitä vastoin 1600-luvun onnittelu-, omistus- ja surunvalittelurunoissa on runsaasti lähinnä omalle vertaisryhmälle tai eliitille suunnattuja runoja. Suullisen runon piirteitä lainaavinakin niiden tyyli oli kirjallista. 
Perinteisesti oppineen runouden virheinä ja väärinkäsityksinä pidetyt ominaisuudet voivat joiltain osin liittyä paitsi heidän tavoitteinaan olleisiin runon lajeihin, myös paikallisten suullisten runokulttuurien luonteeseen. Etenkin säkeiden tavulukujen vaihtelu ja painorakenteiden väljyys lyö niin vahvasti läpi koko suomenkielisen runon varhaishistorian ja lajikirjon, että sen virheenä tai vahinkona pitäminen tuntuu kohtuuttomalta. Näiden piirteiden hyväksyminen osaksi kelvollista runoa edellyttää irrottautumista sekä kirjallisuuden että kansanperinteen tutkimuksen piirissä 1800-luvulta asti vallinneista runousideaaleista. Arvostettu ja hyvä runous on voinut olla paljon muutakin kuin tasalukuista, puhdasta jambia tai klassista kalevalamittaa.

Tutkimusaineistot

ARKistoAineistot

Suomalaisen Kirjallisuuden Seuran arkisto:

SKS KRA: Pelkonen, Martta 256. 1940 (Okulin Luhtanen, Orusjärvi, Salmi). SKSÄ L 427: Äänittäneet Jouko Hautala \& Lauri Simonsuuri, 1952 (Anni Tenisova, Vuokkiniemi).

\section{JULKAISTUT TUTKIMUSAINEISTOT}

Agricola, Mikael I-III: Mikael Agricolan teokset I-III. 1987 [1543-1552]. Porvoo: WSOY. Julkaistu myös digitaalisena editiona: Agricola [online]. Vanhan kirjasuomen korpus. Kotus. < http://kaino.kotus.fi/korpus/vks/meta/agricola/ agricola coll rdf.xml $>$ [15.1.2015.]

Biblia 1642: Biblia: se on: coco pyhä Ramattu. [Loistopainos.] [Stockholmis]: [Henrich Keisari]. Digitoituna: Biblia [online] Doria. Kansalliskirjasto < http:// www.doria.fi/handle/10024/66164 > [1.4.2015.]

Bure, Anders 1626: Orbis arctoi nova et accurata delineatio. Stockholm: Christoffer Reusner. Julkaistu myös käännöksenä: Tuomo Pekkanen 1985: Pohjoismaiden kuvaus v. 1626. SKS: Helsinki.

Codex Westh 2012a: Häkkinen, Kaisa (toim.): Codex Westh. Westhin koodeksin tekstit. Turku: Turun yliopisto.

Codex Westh 2012b: Tuppurainen, Erkki (toim.) 2012: Westhin koodeksin kirkkolaulut. Helsinki: Sibelius-Akatemia.

Finno, Jacobus 1988 [1583]: [Virsikirja]. Näköispainos teoksessa Pentti Lempiäinen (ed.) 1988, Jaakko Finnon Virsikirja. Helsinki: SKS.

Florinus, Henrik 1987 [1702]: Wanhain suomalaisten tawaliset ja suloiset sananlascut. Näköispainos teoksessa Sananlaskut. Helsinki: SKS.

Grotenfelt, Kustavi 1912: Suomenkielisiä historiallisia asiakirjoja Ruotsin vallan ajalta (vuosilta 1548-1809). Acta Historica Fennica. Helsinki: SKS. 
Haapalainen, T. I. \& Tuppurainen, Erkki 2004: Virtuaalikatedraali, Suomen vanhat virsisävelmät [online]. Sibelius-Akatemia, kirkkomusiikin osasto. < www2.siba.fi/virtuaalikatedraali/vanhatvirret/ > [15.1.2015.]

Juslenius, Daniel 1987 [1700]: Vanha ja uusi Turku [Aboa vetus et nova]. Suom. Tuomo Pekkanen \& Virpi Seppälä-Pekkanen. Helsinki: SKS.

Martinius, Matthias 1968 [1689]: Hodegus Finnicus, Eller Finsk Wägwisare. [Holmiae]. Näköispainos 1968: Vanhat kielioppimme. SKS: Helsinki.

Petraeus, Aeschillius 1968 [1649]: Linguae Finnicae Brevis Institutio. [Turku: Petrus Wald]. Näköispainos 1968: Vanhat kielioppimme. SKS: Helsinki.

Porthan, Henrik Gabriel 1983 [1766-1778]: Suomalaisesta runoudesta [De poësi Fennica]. Helsinki: SKS.

SKVR: Suomen Kansan Vanhat Runot. 1908-1997. Eri toimittajia. Helsinki: SKS. Julkaistu myös sähköisenä: SKVR-tietokanta [online]. < http://dbgw.finlit.fi/ skvr/ > [15.5.2015.]

VKK: Vanhan kirjasuomen korpus [online]. Kotus. < http://kaino.kotus.fi/korpus/ vks/meta/vks coll rdf.xml > [15.1.2015.]

AHF: Acta Historica Fennican 1600-Iuvun asiakirjoja. Julk. Grotenfelt 1912. < http://kaino.kotus.fi/korpus/vks/meta/lait/ahf1600 rdf.xml > [15.1.2015.]

As: 1600-luvun asetustekstejä. < http://kaino.kotus.fi/korpus/vks/meta/lait/ as 1600 rdf.xml $>$ [15.1.2015.]

B1: Biblian alkutekstit (nimiö ja omistus) sekä Vanhan testamentin esipuhe. [1642.] < http://kaino.kotus.fi/korpus/vks/meta/biblia/biblia alku rdf.xml > [15.1.2015.] Flor1702: Henricus Florinus: Wanhain Suomalaisten Tawaliset ja Suloiset, Sananlascut. [1702] < http://kaino.kotus.fi/korpus/vks/meta/varia/flor1702 rdf.xml > [20.5.2015]

Hemm1605: [Hemminki Maskulainen: Virsikirja]. [1605.] < http://kaino.kotus.fi/ korpus/vks/meta/virret/hemm1605 rdf.xml > [15.1.2015.]

Hemm 1616: Hemminki [Maskulainen] (suom.): Vanhain Suomen maan Pijspain, ja Kircon Esimiesten Latinan kielised laulud 1616. Näköispainos 1927, Otava. < http://kaino.kotus.fi/korpus/vks/meta/virret/hemm1616 rdf.xml > [15.1.2015.]

Lju: Ljungo Tuomaanpoika (suom.): Ruodzin waldakunnan Maan elj taloin poicain laki 1601. Julk. Martti Ulkuniemi 1975: Ljungo Tuomaanpojan lainsuomennokset. 1. < http://kaino.kotus.fi/korpus/vks/meta/lait/lju.ml rdf.xml > [15.1.2015.]

LPet1658: Laurentius Petri Aboicus: Ajan Tieto / Suomenmaan menoist ja vscost / erinomaisest Suomen Pispoist. [1658.] < http://kaino.kotus.fi/korpus/vks/meta/ Ipetri/lpet1658 rdf.xml > [15.1.2015.]

Menn 1699: [Jonas Mennander:] Huonen-Speili. [1699] < http://kaino.kotus.fi/ korpus/vks/meta/varia/menn1699 rdf.xml > [15.1.2015.]

Wexionius, Michael O. 1650: Epitome descriptionis Sueciae, Gothiae, Fenningiae, et subiectarum provinciarum. Aboae: Wald.

KirJallisuUs

Agha, Asif 2004: Registers of language - Duranti, Alessandro (ed.), A Companion to Linguistic Anthropology. Malden: Blackwell. 23-45.

Asplund, Anneli 1997: Murros, muutos ja mitta: metriikan, rakenteen ja sisällön välisistä suhteista suomalaisissa kansanlauluissa. Julkaisematon lisensiaatintutkimus. S 459 I ja II. Helsingin yliopisto, folkloristiikka. 
Kati Kallio: Kalevalamitta oppineiden käytössä uuden ajan alun Suomessa

Asplund, Anneli 2006: Runolaulusta rekilauluun: kansanlaulun murros - Asplund, Anneli \& Hoppu, Petri \& Laitinen, Heikki \& Leisiö, Timo \& Saha, Hannu \& Westerholm, Simo (toim.) 2006, Suomen musiikin historia 8: Kansanmusiikki. Helsinki: WSOY. 108-159.

Burke, Peter 2009: Popular Culture in Early Modern Europe. Farnham Burlington, VT: Ashgate.

Enäjärvi-Haavio, Elsa 1953: Ritvalan helkajuhla. Porvoo: WSOY.

Foley, John Miles 2002: How to Read an Oral Poem. Urbana and Chicago: University of Illinois Press.

Frog \& Stepanova, Eila 2011: Alliteration in (Balto-) Finnic Languages - Roper, Jonathan (ed.), Alliteration in Culture. Houndmills: Palgrave Macmillan. 195-218.

Gasparov, Mikhail Leonovich 1996: A History of European Versification. Oxford: Claredon Press.

Gillespie, Gerald Ernest Paul 1971: German baroque poetry. New York: Twayne Publishers.

Gummerus, Jaakko 1931: Onko katolisella ajalla ollut suomenkielisiä virsiä? Suomen kirkkohistoriallisen seuran vuosikirja 21: 333-353.

Hallio, Kustaa 1936: Suomalaisen virsikirjan virret: alkuperä ja kehitys. Helsinki: SKS.

Hannikainen, Jorma 2006: Suomeksi suomalaisten tähden. Kansankielisen tekstin ja sävelmän suhde Michael Bartholdi Gunnæruksen suomenkielisessä Officia missæ -introituskokoelmassa (1605). Kuopio: Sibelius-Akatemia.

Harvilahti, Lauri 2012: Finland - Bendix, Regina \& Hasan-Rokem, Galit (eds.), A Companion to Folklore. Malden (MA): Wiley-Blackwell. 391-408.

Hautala, Jouko 1954: Suomalainen kansanrunoudentutkimus. Helsinki: SKS.

Heininen, Simo 2007: Mikael Agricola. Elämä ja teokset. Helsinki: Edita.

Herl, Joseph 2004: Worship wars in Early Lutheranism: Choir, Congregation, and Three Centuries of Conflict. Oxford: Oxford University Press.

Hymes, Dell 1981: 'In vain I tried to tell you': essays in Native American ethnopoetics. Philadelphia: University of Pensylvania Press.

Häkkinen, Kaisa \& Tanja Vaittinen (toim.) 2007: Agricolan aika. Helsinki: BTJ Kustannus.

Häkkinen, Kaisa 2007: Mikael Agricolan elämä ja elämäntyö - Häkkinen, Kaisa \& Vaittinen, Tanja (toim.), Agricolan aika. Helsinki: BTJ Kustannus. 13-23.

Häkkinen, Kaisa (toim.) 2012: Mikael Agricolan runokirja. Turku: Turun yliopisto.

Häkkinen, Kaisa 2013: Kansanrunouden aineksia vanhimmassa suomalaisessa kirjallisuudessa - Hovi, Tuomas \& Hänninen, Kirsi \& Leppälahti, Merja \& Vasenkari, Maria (toim.), Viisas matkassa, vara laukussa: näkökulmia kansanperinteen tutkimukseen. Turku: Turun yliopisto. 56-75.

Joutsivuo, Timo 2010: Papeiksi ja virkamiehiksi - Hanska, Jussi \& VainioKorhonen, Kirsi (toim.), Huoneentaulun maailma. Kasvatus ja koulutus Suomessa keskiajalta 1860-luvulle. Helsinki: SKS. 112-183.

Kallio, Kati 2013: Laulamisen tapoja. Esitysareena, rekisteri ja paikallinen laji länsi-inkeriläisessä kalevalamittaisessa runossa. [online] eThesis. < http:// urn.fi/URN:ISBN:978-952-10-9566-5 > [15.1.2015.]

Kallio, Kati (tulossa): Laulettu kalevalamitta. Artikkelikäsikirjoitus. 
Knuutila, Jyrki 1997: Virsikirjat ja hengelliset laulukirjat. - Laine, Tuija (toim.): Vanhimman suomalaisen kirjallisuuden käsikirja. Helsinki: SKS. 134-143.

Kontio, Sinikka 2001: Veisuun mahti. Vanha virsikirja ja kansanveisuun tyylipiirteiden sovellus omassa musisoinnissa. Helsinki: Sibelius-Akatemia kansanmusiikin osasto.

Korhonen, Mikko 1994: The Early History of the Kalevala Metre - Siikala, Anna-Leena \& Vakimo, Sinikka (eds.), 1994: Songs beyond the Kalevala. Transformations of Oral Poetry. Helsinki: SKS. 75-87.

Krohn, Julius Leopold Fredrik 1862: Suomenkielinen Runollisuus Ruotsinvallan aikana ynnä Kuvaelmia Suomalaisuuden Historiasta. Helsinki.

Krohn, Julius 1880: Suomalaisen Virsikirjan Historia. Helsinki: Kansanvalistuseura.

Kurvinen, Onni 1941: Vanha virsikirja. Vuoden 1701 suomalaisen virsikirjan synty ja sisällys. Rauma: Länsi-Suomen kirjapaino.

Kurvinen, P. J. I. 1929: Suomen virsirunouden alkuvaiheet v:een 1640. Helsinki: SKS.

Kuusi, Matti 1994: Questions of Kalevala metre: what exactly did Kalevala language signify to its users? - Siikala, Anna-Leena \& Vakimo, Sinikka (eds.), Songs beyond the Kalevala. Transformations of Oral Poetry. Helsinki: SKS. 41-55.

Kuusi, Matti 1949: Sampo-eepos. Typologinen analyysi. Helsinki: SuomalaisUgrilainen Seura.

Laitinen, Heikki 2003: Matkoja musiikkiin 1800-luvun Suomessa. Tampere: Tampere University Press.

Laitinen Heikki 2005: Barokki tunteen ja järjen dialogina: Hemminki Maskulaisen Uscovaisen sielun halu Christuxen jälken - Hymnos. Soukat sanat maistaa suu. Hemminki Maskulaisen virsikirja 400 vuotta. Helsinki: Hymnologian ja liturgiikan seura. 143-163.

Laitinen, Heikki 2006: Runolaulu - Asplund, Anneli \& Hoppu, Petri \& Laitinen, Heikki \& Leisiö, Timo \& Saha, Hannu \& Westerholm, Simo (toim.), Suomen musiikin historia 8: Kansanmusiikki. Helsinki: WSOY. 14-79.

Lauerma, Petri 2001: Larin Parasken metriikasta. - Virittäjä 105(1): 44-58.

Lauerma, Petri 2004: Larin Parasken epiikan kielellisestä variaatiosta. Helsinki: SKS.

Lauerma, Petri (toim.) 2012: Rudimenta linguae Finnicae breviter delineata: suomen kielen varhaiskielioppi ja sen tausta. Helsinki: SKS.

Laurila, Vihtori 1956: Suomen rahvaan runoniekat sääty-yhteiskunnan aikana. 1. osa, Yleiset näkökohdat. Helsinki: SKS.

Leaver Robin A. 2007: Luther's Liturgical music. Principles and Implications. Michigan: B. Eerdmans Publishing Co.

Lehtonen, Tuomas 2013: Spoken, Written, and Performed in Latin and Vernacular Cultures from Middle Ages to the Early Seventeenth Century: Ramus Virens Olivarum - Mortensen, Lars Boje \& Lehtonen, Tuomas M. S. with Bergholm, Alexandra (eds.), The Performance of Christian and Pagan Storyworlds. NonCanonical Chapters of the History of Nordic Medieval Literature. Turnhout: Brepols. 107-139. 
Lehtonen, Tuomas (tulossa): Pious hymns and devil's music: Michael Agricola (c. 1507-1557) and Jacobus Finno (c. 1540-1588) on Church song and folk beliefs - Lehtonen, Tuomas \& Kaljundi, Linda (eds.): Re-Forming the Early Modern North. Text, Music and Church Art. Amsterdam: Amsterdam University Press.

Leino, Pentti 1986: Language and metre. Metrics and the metrical system of Finnish. Helsinki: SKS.

Leino, Pentti 1994: The Kalevala Metre and its Development - Siikala, AnnaLeena \& Vakimo, Sinikka (eds.), Songs beyond the Kalevala. Transformations of Oral Poetry. Helsinki: SKS. 56-74.

Lempiäinen, Pentti 2000: Hemminki Henrikinpoika Maskulainen (noin 15501619) - Kansallisbiografia [online]. Helsinki: SKS 1997-. < http://www. kansallisbiografia.fi/kb/artikkeli/2327 > ; $\quad$ URN:NBN:fi-fe20051410 > [15.1.2015.]

Lempiäinen Pentti 2012: Finno, Jacobus (noin 1540-1588) - Kansallisbiografia [online]. Helsinki: SKS 1997-. < http://www.kansallisbiografia.fi/kb/ artikkeli/2310/ > ; U URN:NBN:fi-fe20051410 > [15.1.2015.]

Lempiäinen, Pentti \& Haapalainen, T. I. 1971: Virsiavain. Käsikirja virsikirjan käyttäjille. Helsinki; Kirjapaja.

Leskelä, Ilkka (tulossa): Trade and the known world: Finnish priests' and laymen's networks in the late medieval Baltic Sea region - Lehtonen, Tuomas \& Kaljundi, Linda (eds.), Re-Forming the Early Modern North: Text, Music and Church Art. Amsterdam: Amsterdam University Press.

Lippus, Urve 1995: Linear musical thinking: a theory of musical thinking and the runic song tradition of Baltic-Finnish peoples. Helsinki: University of Helsinki.

Melander, Toini (toim.) 1928: Suomalaista tilapäärunoutta Ruotsin vallan ajalta I. Helsinki: SKS.

Niemi, Jarkko 1998: The Nenets Songs: a structural analysis of text and melody. Tampere: University of Tampere.

Niinimäki, Pirjo-Liisa 2007: "Saa veisata omalla pulskalla nuotillansa." Riimillisen laulun varhaisvaiheet suomalaisissa arkkiveisuissa 1643-1809. Helsinki: Suomen etnomusikologinen seura.

Page, Christian 2010: The Christian west and its singers: the first thousand years. New Haven: Yale University Press.

Pajamo, Reijo \& Tuppurainen, Erkki (toim.) 2004: Suomen musiikin historia 7. Kirkkomusiikki. Helsinki: WSOY.

Pirinen, Kauko 1991: Suomen kirkon historia 1. Keskiaika ja uskonpuhdistuksen aika. Porvoo: WSOY.

Rapola, Martti 1934: Vanhan runon kuvastelua parissa 1500-luvun virressä Kalevalaseuran vuosikirja 14: 149-169.

Reichl, Karl 2000: Introduction: The Music and Performance of Oral Epics - Reichl, Karl (ed.), The Oral Epic: Performance and Music. Berlin: Verlag für Wiss und Bildung. 1-40.

Riikonen, Hannu K. 1999: Till frågan om barocken i finsk litteratur - Malmio, Kristina (red.), Om barocken i Norden. Helsingfors: Helsingfors universitet, Nordica. 63-79.

Saarinen, Jukka 1988: Variaatio Arhippa ja Miihkali Perttusen epiikassa. Julkaisematon pro gadu -tutkielma. S 371 . Helsingin yliopisto, folkloristiikka. 
Kati Kallio: Kalevalamitta oppineiden käytössä uuden ajan alun Suomessa

Saarinen, Jukka (tulossa): väitöskirja Arhippa Perttusen poetiikasta. Helsinki: Helsingin yliopisto.

Sadeniemi, Matti 1951: Die Metrik des Kalevala-verses. Helsinki: Suomalainen tiedeakatemia.

Sarajas, Annamari 1956: Suomen kansanrunouden tuntemus 1500-1700-lukujen kirjallisuudessa. Porvoo: WSOY.

Sarv, Mari 2008: Loomiseks loodud: regivärsimõõt traditsiooniprotsessis. Tartu: Eesti Kirjandusmuuseum.

Schalin, Olav D. 1946-1947: Kulthistoriska studier till belysande av reformationens genomförande i Finland. Helsingfors: SLS.

Siikala, Anna-Leena 2012: Itämerensuomalaisten mytologia. Helsinki: SKS.

Suomi, Vilho 1963a: Suomenkielinen lyriikka ennen vuotta 1640 - Rapola, Matti (toim.), Suomen kirjallisuus II. Ruotsin ajan kirjallisuus. Helsinki: SKS \& Otava. 245-262.

Suomi, Vilho 1963b: Suomenkielinen runous 1640-1743 - Rapola, Matti (toim.), Suomen kirjallisuus II. Ruotsin ajan kirjallisuus. Helsinki: SKS \& Otava. 263-306.

Tarkiainen, Viljo 1922: Piirteitä suomalaisesta kirjallisuudesta. Porvoo: WSOY.

Tarkiainen, Viljo 1929: Mikael Agricolan runot ja virret. Helsinki: Otava.

Tarkka, Lotte 2005: Rajarahvaan laulu. Tutkimus Vuokkiniemen kalevalamittaisesta runokulttuurista 1821-1921. Helsinki: SKS.

Tedlock, Dennis 1983: The Spoken Word and the Work of Interpretation. Philadelphia: University of Pennsylvania Press.

Timonen, Senni 2004: Minä, tila, tunne. Näkökulmia kalevalamittaiseen kansanlyriikkaan. Helsinki: SKS.

Tuppurainen, Erkki 2012: Westhin koodeksi reformaatioajan kirkkomusiikin dokumenttina - Häkkinen, Kaisa (toim.), Tutkimuksia Westhin koodeksista. Turku: Turun yliopiston suomen kielen ja suomalais-ugrilaisen kielentutkimuksen oppiaine. 29-42.

Vartia, Arvo 1907: IImanennustuksia Laviasta - Satakunta. Kotiseututkimuksia I. Helsinki: Satakuntalainen osakunta. 225-228.

Viinamäki, Anna 2005: Hemminki Maskulainen - virsirunoilija [online]. Kotus. $<$ http://kaino.kotus.fi/www/artikkelit/maskulainen/> [15.1.2015.]

Väinölä, Tauno (toim.) 1995: Vanha virsikirja. Vuoden 1701 suomalainen virsikirja. Helsinki: Kirjaneliö.

Filosofian tohtori Kati Kallio on tutkija Suomen Akatemian hankkeessa "Suulliset ja kirjalliset kulttuurit keskiajalla ja uuden ajan alussa: kulttuurinen vaihto, kielimaailmat ja kommunikatiiviset verkostot Itämeren piirissä" (hanke 137906, SKS). 